\title{
The Use of Quinoa and Chia to Improve the Functional Properties and Enhance the Health Benefits of Soft-Serve Ice Milk and Ice Cream
}

\author{
Salah A. Khalifa \\ Food Science Department, Faculty of Agriculture, Zagazig University, 44511 Zagazig, Egypt
}

Received: $21 / 10 / 2020$

\begin{abstract}
This study aimed to evaluate the using of quinoa and chia to improve the functional properties and enhance the health benefits of soft-serve ice milk and ice cream. Treatments were prepared with different proportions of fresh milk, quinoa \& chia flour, cream, and skimmed milk powder to obtain mixes according to fat and total solids ratios. The product was examined for quality by physicochemical, rheological, and sensory properties analysis. The differences in the sensory scores for respective attributes were highly significant $(\mathrm{p} \leq 0.05)$. Treatments with quinoa and chia flour exhibited higher viscosity and improved concentration of polyphenols availability and antioxidant activity. Ice milk CIM (prepared by replacing fresh milk with chia flour) and ice cream CIC (prepared by replacing fresh milk with chia flour) samples took a longer time to melt. Nutritional quality values of ice cream samples were quite high relatively. Ice milk and ice cream prepared by replacing fresh milk with chia and quinoa flour tend to be a benefit to human health due to its low atherogenicity (AI) \& thrombogenicity (TI) index and suitable n-6/n-3 ratio. But, the desaturase activity (DA) had close values between all treatments. The red-green coordinate $\left(a^{*}\right)$ and yellow-blue coordinate $\left(b^{*}\right)$ were significantly higher $(\mathrm{p} \leq 0.05)$ in CIM (ice milk prepared by replacing fresh milk with chia flour), QIM (ice milk with quinoa flour), CIC (ice cream prepared by replacing fresh milk with chia flour), QIC (ice cream with quinoa flour) and lower $(\mathrm{p} \leq 0.05)$ in MIC (control ice cream) and MIM (control ice milk). Due to the nutritional and functional characteristics conferred to the soft-serve ice milk and ice cream, the use of the quinoa (QIC and QIM) and chia flour (CIC) showed an adequate potential to improve the functional properties and enhance the health benefits of soft-serve ice milk and ice cream.
\end{abstract}

Keywords: Quinoa, Chia, Flour, Soft-Serve, Ice Milk, Ice Cream, Nutritional Quality, Colour Properties, Sensory Characteristics

\section{INTRODUCTION}

Soft serve includes ice cream and related products that are sold as drawn directly from the scraped-surface freezer without hardening. Ice cream, frozen custard, low-fat ice cream, or frozen yoghurt can all be served soft-frozen although there are typically slight variations in soft-serve formulations compared to their hard-frozen counterparts. Soft-frozen products are typically prepared at the site of consumption from mixes that have been processed in dairy processing facilities and are packaged and distributed in bulk. Low-fat mixes for soft-serve typically contain 3-5\% fat, $11-14 \%$ milk solids-not-fat, $13-15 \%$ sweetener, and $0.3-0.5 \%$ stabilizer/emulsifier (Goff and Hartel, 2013). Softfrozen dairy desserts appeal to many consumers because of their creamy and smooth texture. Soft-frozen desserts became popular in the 1950 s and remain popular with customers of shops focusing on these products and in fast-food-style restaurants. Less capital is needed by the retailer to get into the soft-serve ice cream business than to make and sell hard-frozen ice cream (Goff and Hartel, 2013).

Consumer demand for healthy food and the increasing prevalence of adverse reactions have created a need for special foods (Pineli et al., 2015). The quinoa seed has received renewed interest, particularly in Western countries due to its high nutritional value. It is especially rich in protein and essential amino acids, contains adequate levels of important micronutrients such as minerals and vitamins, and significant amounts of other bioactive compounds, such as polyphenols. As a versatile substrate ، quinoa has been used for different products (Jeske et al., 2018). Quinoa functional products like a quinoa cereal bar' quinoa flakes, quinoa pasta, have been known to have various health benefits and to be effective in cases of obesity, cardiovascular diseases، hypertension, and celiac disease (AlvarezJubete et al., 2010).

Despite the high nutritional values, the chia seeds are rarely used in food production. The seeds contain fat that is a good source of omega 3 and omega 6 fatty acids. Furthermore, the seeds have a relatively high content of protein of high biological value. They are rich in the essential amino acids, particularly leucine, lysine, isoleucine, and valine (Sandoval-Oliveros and Paredes-López, 2013). Therefore, the seeds can be a complement of cereal proteins that are deficient in the essential amino acids. Additionally، chia seeds have a high dietary fiber content, which is characterized by high-water absorption and the ability to form aqueous solutions with increased viscosity. Chia seeds are an important source of natural antioxidants such as tocopherols، sterols, carotenoids, phenolic compounds including chlorogenic and caffeic acid, quercetin, myricetin, and kaempferol (Reyes-Caudillo et al., 2008). In recent years, the European Parliament approved chia seeds as a novel food. This resulted in an increase in the use of chia seeds in food production (Ullah et al., 2016).

Therefore, the present study aimed to the possibilities of using quinoa and chia flour in the production of soft-serve ice milk and ice cream. Also, determine the impact of quinoa and chia flour on physicochemical, rheology, sensory properties, and nutritional quality. 


\section{MATERIALS AND METHODS}

Materials:

Fresh bulk buffaloes' milk $(82.8 \%$ moisture, $7.5 \%$ fat, $5.2 \%$ lactose, $3.7 \%$ protein, and $0.81 \%$ ash), were standardized to fat content $4 \%$ and fresh sweet cream $(53.2 \%$ moisture, $41 \%$ fat, $2.5 \%$ lactose, $3 \%$ protein, and $0.43 \%$ ash) were obtained from the dairy products unit at Food Science Department, Faculty of Agriculture, Zagazig University.

Quinoa seeds (Chenopodium quinoa Willd.) were purchased from the Egyptian Natural Oils Company, Cairo، Egypt. Chia seeds (Salvia hispanica L.), were obtained from Field Crops Research Inst., Agric. Res. Center, Giza-Egypt. The quinoa and chia seeds were milled and ground into flour and sieving through 40 mesh screens using a hammer mill. Then the resultant quinoa and chia flour was packed and kept in the refrigerator temperature until used.

The characteristics of flour indicated by the manufacturer were as follows: quinoa flour $(10 \%$ moisture, $13.5 \%$ protein $(\mathrm{N} \times 5.70), 6.5 \%$ fat, $68.4 \%$ total carbohydrates, and $1.8 \%$ ash); chia flour $(4.53 \%$ moisture, $23.11 \%$ protein $(\mathrm{N} \times 5.70), 34.50 \%$ fat, 33 . $87 \%$ total carbohydrates, and $3.65 \%$ ash).

Valio ${ }^{\circledR}$ skimmed milk powder (SMP) spray driedlow heat $(3.9 \%$ moisture, $1.3 \%$ fat, $52 \%$ lactose, $35 \%$ protein, and $7.8 \%$ ash) was obtained from Valio Haapavesi Plant, Finland. Stabilizer (Guar gum E412, sodium carboxymethyl cellulose E466, and mono and diglyceride of fatty acid E471 (1:1:1)), was obtained from the Egyptian Company for Dairy Products and Food Additives "EGY- DAIRY ( $10^{\text {th }}$ of Ramadan city,
Egypt). Commercial grade sugar (sucrose) and vanilla were obtained from a local market. Maltodextrin De 1520 was obtained from the National Company for Maize Products (NCMP), Egypt.

\section{Methods:}

\section{Preparation of ice cream}

Soft-serve ice cream (Softy) mixes were prepared according to Goff and Hartel (2013). The formulation was prepared to obtain ice milk and ice cream according to fat and total solids ratios, the proportions of adding quinoa and chia flour were calculated according to fat and total solids ratios in mixes (Chandan and Kilara, 2011). Table (1) shows the formulations of the different prepared mixes. Skim milk powder (SMP) and flour (quinoa or chia) were first mixed with sugar, stabilizer, and $0.5 \%$ vanilla to generate a "dry mix". Fresh milk was preheated to $40^{\circ} \mathrm{C}$ followed by the addition of fresh cream, the temperature was raised to $60^{\circ} \mathrm{C}$ and the "dry mix" was slowly added to the "liquid mix" with gentle stirring. The mix, at the temperature of $60 \pm 2^{\circ} \mathrm{C}$, was homogenized using a double-stage homogenizer to prevent fat clumping at $15 \mathrm{MPa}$ in the first stage and at 3.5 $\mathrm{MPa}$ in the second stage. The mixture was then heated for $80^{\circ} \mathrm{C} / 30 \mathrm{sec}$, followed by cooling to $4-5^{\circ} \mathrm{C}$ and aged in the fridge for $4 \mathrm{hrs}$. The aged ice cream mixes were mixed well, freezed, and whipped in the ice cream maker (Taylor C712, Soft Serve Freezer Twist, Pump, Taylor Company, Blackhawk Blvd. Rockton, Illinois, USA). The ice cream was collected at an exit temperature of $-7 \pm 1^{\circ} \mathrm{C}$, placed in $100 \mathrm{ml}$ plastic cups to the consumer directly (for sensory evaluation), covered, and stored at $-20^{\circ} \mathrm{C}$ until analysis.

Table (1): The different formulations of ice milk and ice cream mix ingredients $(\mathrm{Kg} / 100 \mathrm{Kg}$ mix) and chemical properties

\begin{tabular}{|c|c|c|c|c|c|c|}
\hline \multirow{3}{*}{ Ingredients } & \multicolumn{6}{|c|}{ Treatments } \\
\hline & \multicolumn{3}{|c|}{ Ice milk } & \multicolumn{3}{|c|}{ Ice cream } \\
\hline & MIM & QIM & CIM & MIC & QIC & CIC \\
\hline Fresh milk & 74.6 & - & - & 60.8 & - & - \\
\hline Quinoa flour & - & 14 & - & - & 9.7 & - \\
\hline Chia flour & - & - & 10 & - & - & 5 \\
\hline Cream & 2.5 & 7.8 & 1.2 & 19 & 23.4 & 20.5 \\
\hline Skim milk powder & 5.3 & 0.5 & 6.9 & 5.1 & 3 & 8.3 \\
\hline Sucrose & 12 & 12 & 12 & 11 & 11 & 11 \\
\hline Maltodextrin & 4.5 & 4.5 & 4.5 & 3 & 3 & 3 \\
\hline Vanilla & 0.5 & 0.5 & 0.5 & 0.5 & 0.5 & 0.5 \\
\hline Stabilizer/emulsifier & 0.6 & 0.6 & 0.6 & 0.6 & 0.6 & 0.6 \\
\hline Water & 0 & 60.1 & 64.3 & 0 & 48.8 & 51.1 \\
\hline Total & 100 & 100 & 100 & 100 & 100 & 100 \\
\hline \multicolumn{7}{|l|}{ Chemical properties: } \\
\hline Total solids (\%) & $34.02 \pm 0.18^{\mathrm{a}}$ & $34.01 \pm 0.82^{\mathrm{a}}$ & $34.06 \pm 0.94^{\mathrm{a}}$ & $37.06 \pm 0.79^{\mathrm{a}}$ & $37.28 \pm 0.17^{\mathrm{a}}$ & $37.08 \pm 0.37 \mathrm{a}$ \\
\hline Total protein $(\%)$ & $4.63 \pm 0.09^{\mathrm{a}}$ & $2.28 \pm 0.03^{\mathrm{c}}$ & $4.68 \pm 0.07^{\mathrm{a}}$ & $4.52 \pm 0.12^{\mathrm{a}}$ & $2.98 \pm 0.15^{\mathrm{b}}$ & $4.55 \pm 0.06^{\mathrm{a}}$ \\
\hline Total fat $(\%)$ & $4.03 \pm 0.06^{\mathrm{b}}$ & $4.01 \pm 0.18^{\mathrm{b}}$ & $4.04 \pm 0.08^{b}$ & $10.07 \pm 0.14^{\mathrm{a}}$ & $10.00 \pm 0.02^{\mathrm{a}}$ & $10.02 \pm 0.16^{\mathrm{a}}$ \\
\hline Total ash (\%) & $1.03 \pm 0.06^{\mathrm{a}}$ & $0.32 \pm 0.04^{\mathrm{e}}$ & $0.91 \pm 0.14^{\mathrm{bc}}$ & $0.97 \pm 0.18^{\mathrm{ab}}$ & $0.51 \pm 0.08^{\mathrm{d}}$ & $0.84 \pm 0.06^{\mathrm{c}}$ \\
\hline Milk-solids-non-fat (\%) & $12.66 \pm 0.12^{\mathrm{a}}$ & $12.66 \pm 0.16^{\mathrm{a}}$ & $12.69 \pm 0.36^{\mathrm{a}}$ & $12.08 \pm 0.16^{\mathrm{b}}$ & $12.03 \pm 0.14^{\mathrm{b}}$ & $12.16 \pm 0.28^{\mathrm{b}}$ \\
\hline Total carbohydrate (\%) & $24.34 \pm 0.48^{\mathrm{b}}$ & $27.40 \pm 1.24^{\mathrm{a}}$ & $24.44 \pm 0.88^{\mathrm{b}}$ & $21.50 \pm 0.78^{\mathrm{c}}$ & $23.80 \pm 0.64^{\mathrm{b}}$ & $21.68 \pm 0.70^{\mathrm{c}}$ \\
\hline Total calories (Kcal/100g) & $149.35 \pm 1.30^{\mathrm{e}}$ & $150.97 \pm 0.10^{\mathrm{d}}$ & $150.02 \pm 0.48^{\mathrm{de}}$ & $186.27 \pm 1.96^{\mathrm{c}}$ & $192.70 \pm 0.70^{\mathrm{a}}$ & $191.37 \pm 1.42^{b}$ \\
\hline
\end{tabular}

Mean $( \pm$ SD)

${ }_{a, b, c}$ Values in the same row having different superscripts differ significantly $(p \leq 0.05)$.

$\mathrm{MIM}=$ control ice milk, QIM= ice milk prepared by replacing fresh milk with quinoa flour, and CIM= ice milk prepared by replacing fresh milk with chia flour; $\mathrm{MIC}=$ control ice cream, $\mathrm{QIC}=$ ice cream prepared by replacing fresh milk with quinoa flour, and CIC= ice cream prepared by replacing fresh milk with chia flour. 


\section{Physico-chemical analyses:}

The total solids, fat, protein, and ash contents were determined as described by AOAC (2007). The $\mathrm{pH}$ value was determined using a $\mathrm{pH}$ meter (Persica model $\mathrm{pH}$ 900، Switzerland). Carbohydrate content was calculated by difference TS- (fat + protein + ash) according to Guzmán-González et al. (1999). The caloric value was calculated by the following equation given (Chandan and Kilara, 2011), Calories value = $($ protein $\times 4.27)+($ fat $\times 8.79)+($ carbohydrate $\times 3.87)$ as $\mathrm{Kcal} / 100 \mathrm{ml}$ of the product. Apparent viscosity measurements of ice cream mixes were carried out according to Mitschka (1982). Brook field Programmable Rheometer (Model RVDV-III Ultra, Brookfield Engineering Laboratories, Stoughton, MA, USA) was used for viscosity measurements. All mixes were tempered for $5 \mathrm{~min}$ at $20 \pm 1^{\circ} \mathrm{C}$ in a concentric cylinder with RV spindle number 3 at $40 \mathrm{rpm}$. Rheocalc software (ver. 2.5, Brookfield Engineering Laboratories, Inc.) was used to collect the values of apparent viscosity. Plastic viscosity, yield stress, flow behavior index, and consistency coefficient index were drowning from measured values of shear stresses and apparent dynamic viscosity. Ice cream mixes and resultant ice cream were analyzed for specific gravity and freezing point, overrun, and meltdown resistance according to Goff and Hartel (2013). The weight per gallon $(\mathrm{kg})$ of ice cream samples was determined by multiplying the specific gravity of ice cream by the factor 3.786 (Burke, 1947).

\section{Colour measurement:}

Colour attributes of the soft ice milk and ice cream ( $\mathrm{L}^{*}, \mathrm{a}^{*}$ and $\left.\mathrm{b}^{*}\right)$ were performed using Hunter Lab colour analyzer (Hunter Lab Color Flex EZ, USA) according to Chen et al. (1997). The $\mathrm{L}^{*}$ value (lightness index scale) ranges from 0 (black) to 100 (white) while, $a^{*}$ value indicates the redness $(+a)$ or greenness $\left(a^{*}\right)$ and the $b^{*}$ value refers to the yellowness $(+b)$ or blueness $\left(b^{*}\right)$. Samples were placed in Petri dishes and filled to the top. The petri dish was placed directly on the colorimeter sensor. The colour intensity $(\mathrm{C})$, the hue angle $\left(\mathrm{h}_{\mathrm{ab}}\right)\left(0^{\circ}\right.$ or $360^{\circ}=$ purplishred, $90^{\circ}=$ yellow, $180^{\circ}=$ bluish-green, $270^{\circ}=$ blue $)$, whiteness index (WI) and total colour difference $(\Delta \mathrm{E})$ in comparison to an untreated control, were calculated as:

$$
\begin{gathered}
C=\left(a^{* 2}+b^{* 2}\right)^{0.5} \\
h_{\mathrm{ab}}=\arctan \left(b^{* / a}\right) \\
\mathrm{WI}=\mathbf{1 0 0}-\left[(\mathbf{1 0 0}-\mathrm{L} *)^{2}+\mathbf{a}^{* 2}+\mathbf{b}^{* 2}\right]^{0.5} \\
\mathbf{R I}=\mathbf{a} / \mathbf{b}^{*} \\
\Delta \mathrm{E}=\left[\left(L-L_{0}\right)^{2}+\left(a-a_{0}\right)^{2}+\left(b-b_{0}\right)^{2}\right]^{0.5}
\end{gathered}
$$

Where: $L_{0}, a_{0}$ and $b_{0}$ were the $L, a$, and $b$ values of the reference sample which here is the control samples.

The Browning Index $\left(\mathrm{BI}^{*}\right)$ was calculated as described by Palou et al. (1999) using the following formula:

$$
\text { Browning index }\left(\mathrm{BI}^{*}\right)=[100(\mathrm{x}-0.31)] / 0.172
$$

Where: $\quad \mathrm{x}=(\mathrm{a}+1.75 \mathrm{~L}) /(5.645 \mathrm{~L}+\mathrm{a}-3.012 \mathrm{~b})$
Total phenolic and antioxidant activity analyses

Preparation of water ice cream extract:

Ice cream samples (10 g) was mixed with $2.5 \mathrm{ml}$ distilled water and the $\mathrm{pH}$ was adjusted to 4.0 using $1 \mathrm{M}$ $\mathrm{HCl}$. The ice cream samples were then incubated in a water bath $\left(45^{\circ} \mathrm{C}\right)$ for $10 \mathrm{~min}$ and the precipitated proteins were removed by centrifugation $(10,000 \mathrm{rpm}$, $\left.10 \mathrm{~min}, 4^{\circ} \mathrm{C}\right)$. The supernatant was harvested and the $\mathrm{pH}$ was adjusted to 7.0 using $\mathrm{NaOH}(0.5 \mathrm{M})$ followed by another centrifugation $\left(10,000 \mathrm{rpm}, 10 \mathrm{~min}, 4^{\circ} \mathrm{C}\right)$ to remove residual precipitated proteins and salts. The supernatant was harvested, kept refrigerated, and used for subsequent analysis within $24 \mathrm{~h}$, packed, and stored in amber bottles in a freezer $\left(-20^{\circ} \mathrm{C}\right)$ until analysis.

\section{Total phenolic content assay:}

The total phenolic contents were determined as described by Shetty et al. (1995). Absorbance at 725 $\mathrm{nm}$, using a spectrophotometer (model 2010, Cecil Instr. Ltd., Cambridge, UK), was converted to total phenolics expressed in micrograms equivalents of gallic acid per gram ( $\mu \mathrm{g} \mathrm{GAE} / \mathrm{g}$ ) sample. Standard curves were established using various concentrations of gallic acid $(5-60 \mu \mathrm{g} / \mathrm{ml})$ in methanol.

Determination of antioxidant activity (radical scavenging activity, RSA \%):

Free radical scavenging activities (RSA \%) of the samples were measured using the method of Shetty et al. (1995). Water ice cream extract $(250 \mu \mathrm{l})$ was added into $3 \mathrm{ml}$ of $60 \mu \mathrm{M}$ 1,1-diphenyl-2-picrylhydrazyl radical (DPPH) in ethanol. The mixture was shaken vigorously and allowed to stand at room temperature for several minutes. The absorbance was then measured at $517 \mathrm{~nm}$ by a UV-visible spectrophotometer (model 2010, Cecil Instr. Ltd., Cambridge, UK). The readings were compared with the control which contained distilled water $(250 \mu \mathrm{l})$ instead of water ice cream extract. The $\%$ inhibition was calculated by

$\%$ inhibition $=$ [Absorbance control - Absorbance extract $] /$ [Absorbance control] $\times \mathbf{1 0 0}$.

\section{Fatty acid profile:}

The total lipids were extracted from ice cream samples according to the method described by Folch et al. (1957). Fatty acids composition was analyzed by gas chromatography (GC, Agilent 7820A) equipped with an autosampler, a flame ionization detector, and an ionic liquid capillary column (TRACE TR-FAME, $60 \mathrm{~m} \times$ $0.25 \mathrm{~mm} \times 0.25 \mu \mathrm{m}$, Thermo Fisher, USA). The identification of fatty acids was conducted by comparing the retention times of GC peaks with those of corresponding known standards.

The atherogenicity (AI) and thrombogenicity (TI) index were calculated using the equations of Ulbricht and Southgate (1991) as follows:

$$
\begin{aligned}
\mathrm{IA}= & (\text { Lauric }+(4 \times \text { Myristic })+\text { Palmitic }) /(\text { MUFA }+ \text { PUFA }) ; \\
\mathrm{IT}= & (\text { Myristic }+ \text { Palmitic }+ \text { Stearic }) /(0.5 \times \text { MUFA })+ \\
& (0.5 \times \mathrm{n} 6)+(3 \times \mathrm{n} 3)+(\mathrm{n} 3 / \mathrm{n} 6) .
\end{aligned}
$$

Desaturase activity (DA) following the model proposed by Yang et al. (2018): 
$\mathrm{DA}=\operatorname{Sum} \Delta^{9}$ desaturase products $/$ Sum $\Delta^{9}$ desaturase substrates + products;

Sum of $\Delta^{9}$ desaturase products $=$ (Myristoleic + Palmitoleic + Oleic + Conjugated linoleic);

Sum of $\Delta^{9}$ desaturase substrates $=($ Myristic + Palmitic + Stearic + Elaidic).

The health-promoting index (HPI) was proposed by Chen et al. (2004) to assess the nutritional value of dietary fat, which focuses on the effect of fatty acids composition on cardiovascular disease (CVD). The formula is:

\section{HPI $=\Sigma$ SUFA/ [C12: $0+(4 \times$ C14: 0$)+$ C16: 0$]$. Amino acid analysis}

Amino acids were determined according to the AOAC (2007) method with some modifications. Amino acids were analyzed by using reverse-phase highperformance liquid chromatography (Agilent 1100 HPLC; Agilent Ltd., Palo Alto, CA, USA). The amino acids composition was expressed as grams of amino acids per $100 \mathrm{~g}$ of protein.

\section{Nutritional Characterization}

Chemical Score (CS) estimates the amount of protein required to provide the minimal essential amino acids (EAA) pattern for adults, which was recently redefined by FAO/WHO (1991). It was calculated using the equation, the sequence of limiting essential amino acids (EAA) corresponds to the list of EAA, having the lowest chemical score and the protein score indicates the chemical score of the most limiting EAA present in the test protein described by Block and Mitchel (1946). Essential Amino Acid Index (EAAI) estimates the quality of the test protein, using its EAA content as the criterion Oser (1959). EAAI was calculated according to the equation:

$$
\mathrm{EAAI}=\sqrt[n]{\frac{L y s_{p}}{L y s_{s}} \times \frac{T r y_{p}}{T r y_{s}} \times \ldots \times \ldots \times \ldots \times \frac{H i s_{p}}{H i s_{s}}}
$$

In which the subscript $p$ refers to the food protein; $s$, the stander protein (whole egg); and $n$, the number of amino acids entering into the calculation.

Biological value (BV) and net protein utilization (NPU) were calculated using the equations suggested by Oser (1959) and Block and Mitchell (1946):

$$
\begin{aligned}
& \mathrm{BV}=((1.09 \times \mathrm{EAAI}) \quad 11.70) ; \\
& \mathrm{NPU}=\mathrm{BV} \times \text { Digestibility }(\text { protein } 95 \%) .
\end{aligned}
$$

Protein efficiency ratio (PER) based on the amino acid contents were calculated according to the recommendations of Alsmeyer et al. (1974) using the following equations:

$$
\begin{aligned}
\text { PER } 1= & -0.684+0.456 \text { (leucine) }-0.047 \text { (proline) } \\
\text { PER2 }= & -0.468+0.454 \text { (leucine) }-0.105 \text { (tyrosine) } \\
\text { PER3 }= & -1.816+0.435 \text { (methionine) }+0.78 \text { (leucine) } \\
& +0.211 \text { (histidine) }-0.944 \text { (tyrosine) }
\end{aligned}
$$

The Nutritional Index (NI) normalizes the qualitative and quantitative variations of the test protein compared to its nutritional status. NI was calculated using the equation of Chang and Hayes (1978) which considers all the factors with equal importance:

$$
\mathrm{NI}=(\mathrm{EAA} \times \text { Protein }(\mathrm{g} / 100 \mathrm{~g}) / 100) .
$$

\section{Sensory evaluation:}

The sensory evaluation of soft ice-cream was subjected to a panel of 11 judges from the staff member of the Food Science Department, Faculty of Agriculture, Zagazig University, Egypt. Ice cream samples were taken after leaving the machine and immediately presented to committee members. Sensory evaluations of appearance, flavour, body and texture, total acceptance, intensity of coldness, firmness, viscosity, degree of smoothness (Coarseness), liquefying rate were assessed using 9-point scale, according their definitions as described by Bahram Parvar et al. (2010).

\section{Statistical analysis:}

The data were analysed using SPSS version 20.0. The mean and standard deviations of means $( \pm$ SD) of the triplicate analyses of the samples were calculated. The analysis of variance (ANOVA) was performed to determine significant differences between the means; while the means were separated using the new Duncan multiple range test at $\mathrm{p} \leq 0.05$.

\section{RESULTS AND DISCUSSION}

\section{Properties of ice cream mixes:}

The approximate composition of commercial softserve ice milk and ice cream by formulation category of low-fat ice cream or ice milk (4\% milk fat, $12-14 \%$ milk solids-not-fat and $30-34 \%$ total solids) and ice cream or standard ice cream (10\% milk fat, $10-12 \%$ milk solidsnot-fat and $36-38 \%$ total solids) as described by Chandan and Kilara (2011).

Goff and Hartel (2013) reported that the soft-serve mixes when fat content below about $4 \%$ increases risks of having a coarse or icy texture and weak body. A fat content above about $12 \%$ is associated with a significant risk of churning in the freezer and a greasy mouth coating. Much of the soft-serve mix in the market is 4$7 \%$ fat (ice milk or light ice cream). As mentioned, the typical formulas for full-fat ice cream used as soft serve contain 2-3\% less sugar than do formulas for regular ice cream. The milk-solids-non-fat (MSNF) content varies inversely with fat content and may be as high as $14 \%$ for a low-fat formula. Generally, while the fat content is kept lower, the MSNF content is higher than for hardfrozen products. Lactose crystallization is not a problem in these products, as they are consumed immediately after freezing. The sugar content ranges from 13 to $15 \%$, which is somewhat lower than for regular ice cream. Sweetener content must balance with the amount of lactose from the MSNF to provide the right consistency (freezing point and ice phase volume are affected) at the appropriate draw temperature, so higher MSNF contents suggest lower sugar contents.

The physical and rheological properties of different ice milk and ice cream mixes are presented in Table (2). The $\mathrm{pH}$ values of the ice cream mixes were nearly the same and had no significant ( $p \geq 0.05)$ effect on the ice cream mixes (Table 2). Ice milk mixes (MIM, 
QIM and CIM) had higher specific gravities and weight per gallon values than ice cream (MIC, QIC, and CIC). Freezing point depression is the difference between $0^{\circ} \mathrm{C}$ and the temperature at which an ice cream mix first begins to freeze. Freezing does not begin until the mix has cooled below its freezing point. However, a mix with a lower freezing point temperature will produce less ice when drawn to the same temperature as a mix with a higher freezing point and thus, will have a shorter freezing time. Freezing point depression (FPD) is a critical parameter in ice cream production as it influences the initial and gradual growth of the mean size of the formed ice crystals and their native thermodynamic instability (Hartel, 2019). Results showed that the ice milk mixes (MIM, QIM, and CIM) had the highest freezing point (Table 2). Usually, the freezing point is depressed as the serum phase concentration is increased or as the solutes molecular weight is decreased (Hartel, 2019). Results showed a significant difference in FPD between ice cream (MIC, QIC, and CIC) and other ice milk mixes (MIM, QIM, and CIM) which can be attributed to the differences in solids not fat (SNF) contents and ice cream (MIC, QIC, and CIC) contain land $1.5 \%$ less sugar and maltodextrin respectively than do formulas for ice milk. Ohmes et al. (1998) revealed that when fat was removed from ice cream and replaced with non fat milk solids or other dissolved substances, the freezing point was lowered.

The rheological characteristics of different ice cream mixes are shown in Table (2). Chia ice milk mix (CIM) had higher rheological properties expressed as apparent viscosity, plastic viscosity, yield stress and consistency coefficient index than ice cream (CIC) mix. Differently, flow behaviour index took an opposite trend to viscosity. Addition of chia flour (CIM and CIC) or quinoa flour (QIM and QIC), increased significantly the rheological parameters, except for the flow behaviour index.

Capitani et al. (2012 and 2013) reported that the chia seeds have a high dietary fiber content, which is characterized by high-water absorption and the ability to form aqueous solutions with increased viscosity. Olivos-Lugo et al. (2010) found that the chia seeds are high in dietary fiber $(34.6 \%)$, protein $(24.6 \%)$, and oil contents $(32.2 \%)$. The dietary fiber content of the seed has implications on its functional characteristics in food applications. Functional properties impacted by the dietary fiber include fat-binding and gel-forming. Chia flour had approximately $29.17 \%$ crude fiber content compared to chia seed $25.55 \%$ (Coorey et al., 2014). Chia seeds are high in total dietary fiber fractions of chia (Salvia hispanica) were $56.46 \mathrm{~g} / 100 \mathrm{~g}$ (insoluble dietary fiber $53.01 \%$ and soluble dietary fiber 3.45 $\mathrm{g} / 100 \mathrm{~g}$ ) (Jaddu, and Yedida, 2018). The fiber-rich fraction (FRF) for chia (Salvia hispanica) flour had $29.56 \mathrm{~g} / 100 \mathrm{~g}$ crude fiber content and $56.46 \mathrm{~g} / 100 \mathrm{~g}$ total dietary fiber (TDF) content, of which $53.45 \mathrm{~g} / 100$ $\mathrm{g}$ was insoluble dietary fiber (IDF) and $3.01 \mathrm{~g} / 100 \mathrm{~g}$ was soluble dietary fiber (SDF) (Alfredo et al., 2009). Kurek et al. (2018) determined the contents of dietary fiber in quinoa flour and seeds samples. They found $9.54 \%$ of total dietary fiber, insoluble dietary fiber $5.66 \%$ and $3.88 \%$ soluble dietary fiber for quinoa flour, and $16.43 \%, 13.20 \%$ and $3.23 \%$ for quinoa seeds, respectively. Repo-Carrasco-Valencia and Serna (2011) determined the contents of dietary fiber in raw quinoa samples. They found $1.92-3.38 \%$ crude fiber content and $13.72-15.99 \%$ of total dietary fiber, insoluble dietary fiber $11.99-14.39 \%$ and $1.41-1.60 \%$ soluble dietary fiber for raw quinoa. Quinoa proteins do not facilitate a network-forming matrix and gel strength is weak, unlike other proteins' such as casein in bovine milk, as shown also by Mäkinen et al. (2015).

The content of TPC and the antioxidant activity of ice milk and ice cream mixes after aging are shown in Table (2). There was a significant difference $(\mathrm{p} \leq 0.05)$ between QIM and CIM (ice milk) and QIC and CIC (ice cream) for values of TPC and antioxidant activity of fresh samples. Nonetheless, the changes of TPC and antioxidant activity for ice milk and ice cream mixes are due to the differences in the quantities of quinoa and chia flour added in each of the ice milk mixes (QIM and CIM) and ice cream (QIC and CIC), and secondly to the differences in the quantities of added dairy products as well as the amount of sugar (sucrose).

The addition of a great amount of quinoa and chia flour of the ice milk mixes (QIM and CIM) increased significantly $(\mathrm{p} \leq 0.05)$ both of TPC and antioxidant activity compared with the ice cream (QIC and CIC), containing fewer quantities of quinoa and chia flour. Therefore, QIM, CIM, QIC and CIC respectively, had the highest levels of TPC and antioxidant activity compared with control samples (MIM and MIC). Thus, using quinoa and chia flour could improve the TPC and the antioxidant activity of the ice milk and ice cream.

Quinoa rich in protein and essential amino acids contains adequate levels of important micronutrients such as minerals and vitamins, and significant amounts of other bioactive compounds, such as polyphenols (Alvarez-Jubete et al., 2010)

\section{Properties of ice cream mixes: \\ Physicochemical properties:}

The changes in the physical properties of different ice milk and ice cream are presented in Table (2). Incorporation of air into ice cream is rapid, within seconds, and at the same timer the viscosity of the surrounding matrix is increasing exponentially due to freezing, such that air bubbles, after formation, become physically entrapped into a semisolid matrix, making their collapse quite difficult. Loss of air can lead to a defect known as shrinkage, the occurrence of which is fairly and responsible for the loss of quality and acceptability of the product (Dubey and White, 1997). Incorporation of air in ice cream mix during the freezing process decreased the specific gravity of ice cream and consequently decreases its weight per gallon. It was noticed that the specific gravity of ice cream (CIC) than ice milk. While no significant differences were observed in weight per gallon between treatments. In addition, ice cream (CIC, QIC, and MIC) tended to have higher ( $\mathrm{p} \leq$ 0.05 ) overrun \% than ice milk (CIM, QIM, and MIM), respectively. This may be due to the high contribution of fat to the stability of air phase of ice cream during freezing and whipping (Goff et al., 1999). Milk proteins are well known for their ability to form foams. Foaming 
is important during the manufacture of ice cream, because air is incorporated to about $50 \%$ of the phase volume. Milk proteins contribute to stabilizing the air interface in ice cream. This air interface is important for the overall structure and structural stability (Turan et al. 1999).

Ice cream (CIC, QIC, and MIC) showed significantly higher $(\mathrm{p} \leq 0.05)$ overrun than that of ice milk (CIM, QIM, and MIM) which can be attributed to the high viscosity of mix containing quinoa and chia flour (Table 2). The increase in viscosity ran parallel to the increase in the added chia flour in ice cream CIC. Furthermore, the decrease in the total protein content of treated sample QIC and QIM compared with other samples do not affect the overrun percentage probably due to increased air bubbles stability by the compounds and proteins of quinoa flour.

Ice milk and ice cream melting are important in two ways melting in the mouth during consumption and meltdown related to storage at warm temperatures. Table (2) shows the melting rate (structural collapse) of ice cream as represented by the weight loss of the tested samples during $20 \mathrm{~min}$. at room temperature $\left(25 \pm 1^{\circ} \mathrm{C}\right)$. Ice milk CIM and ice cream CIC samples took a longer time to melt and were liquid, than QIM, QIC, MIC and MIM, respectively. The contribution of dietary fiber to the structural characteristics and heat conductivity of ice cream can explain the former effects Olivos-Lugo et al. (2010). The dietary fiber has implications on its functional characteristics in food applications. Functional properties impacted by the dietary fiber include fat-binding and gel-forming.

Fat globules in ice cream mix are in a partially solidified state based on the broad range of triacylglycerol molecules that make up milk fat or other saturated fats that are used for ice cream manufactures such as coconut oil or palm kernel oil. That is' the fat triacylglycerols with high melting points are crystalline in ice cream mix while those with low melting points are in liquid form. It is during cooling after pasteurization and then aging of the mix that most of the fat crystallization takes place. Typically, about $2 / 3$ of milk fat will crystallize at $4{ }^{\circ} \mathrm{C}$ and this has fully crystallized after 4-5 h of aging (Adleman and Hartel, 2001). Thus, as a rule، fractionated milk fats or nondairy fats are usually selected that provide about 50 $70 \%$ solid fat at $4^{\circ} \mathrm{C}$ (Persson, 2009).

Huppertz et al. (2011) also demonstrated the importance of protein structure in the unfrozen phase by the use of high-pressure hydrostatic processing of mix to rearrange the casein proteins into a micellar network of sorts, which resulted in very smooth ice cream of high viscosity with a higher melting resistance.

Table (2): Physicochemical, rheological properties, total phenolic, and radical scavenging activity of different mixes and resulted of ice milk and ice cream

\begin{tabular}{|c|c|c|c|c|c|c|}
\hline \multirow{3}{*}{ Parameter } & \multicolumn{6}{|c|}{ Treatments* } \\
\hline & \multicolumn{3}{|c|}{ Ice milk } & \multicolumn{3}{|c|}{ Ice cream } \\
\hline & MIM & QIM & CIM & MIC & QIC & CIC \\
\hline \multicolumn{7}{|l|}{ Mix after aging: } \\
\hline pH value & $6.47 \pm 0.08^{\mathrm{a}}$ & $6.44 \pm 0.10^{\mathrm{a}}$ & $6.38 \pm 0.20^{\mathrm{a}}$ & $6.43 \pm 0.18^{\mathrm{a}}$ & $6.41 \pm 0.20^{\mathrm{a}}$ & $6.37 \pm 0.08^{\mathrm{a}}$ \\
\hline Specific gravity (kg / L) & $1.120 \pm 0.14^{\mathrm{a}}$ & $1.120 \pm 0.04^{\mathrm{a}}$ & $1.120 \pm 0.06^{\mathrm{a}}$ & $1.101 \pm 0.02^{\mathrm{a}}$ & $1.102 \pm 0.01^{\mathrm{a}}$ & $1.101 \pm 0.08^{\mathrm{a}}$ \\
\hline Weight per gallon (kg) & $4.24 \pm 0.48^{\mathrm{a}}$ & $4.24 \pm 0.26^{\mathrm{a}}$ & $4.24 \pm 0.38^{\mathrm{a}}$ & $4.17 \pm 0.14^{\mathrm{a}}$ & $4.17 \pm 0.18^{\mathrm{a}}$ & $4.17 \pm 0.16^{\mathrm{a}}$ \\
\hline Freezing point $\left({ }^{\circ} \mathrm{C}\right)$ & $-2.49 \pm 0.04^{\mathrm{b}}$ & $-2.49 \pm 0.12^{\mathrm{b}}$ & $-2.49 \pm 0.16^{\mathrm{b}}$ & $-2.32 \pm 0.04^{\mathrm{a}}$ & $-2.32 \pm 0.10^{\mathrm{a}}$ & $-2.32 \pm 0.06^{\mathrm{a}}$ \\
\hline Apparent viscosity (mPas) & $327.68 \pm 4.64^{\mathrm{e}}$ & $353.34 \pm 5.32^{c}$ & $398.78 \pm 2.44^{\mathrm{a}}$ & $339.21 \pm 5.58^{\mathrm{d}}$ & $341.25 \pm 6.50^{\mathrm{d}}$ & $377.64 \pm 6.72^{b}$ \\
\hline Plastic viscosity (mPas) & $163.84 \pm 4.32^{\mathrm{e}}$ & $185.97 \pm 5.06^{\mathrm{bc}}$ & $196.44 \pm 6.12^{\mathrm{a}}$ & $180.43 \pm 7.14^{\mathrm{d}}$ & $182.61 \pm 2.78^{\mathrm{cd}}$ & $188.82 \pm 2.36^{\mathrm{b}}$ \\
\hline Yield stress $\left(\mathrm{N} \mathrm{m}^{-2}\right)$ & $9.10 \pm 0.80^{\mathrm{d}}$ & $12.13 \pm 0.90^{\mathrm{b}}$ & $13.79 \pm 0.42^{\mathrm{a}}$ & $11.02 \pm 0.66^{\mathrm{c}}$ & $11.28 \pm 0.78^{\mathrm{c}}$ & $12.59 \pm 0.73^{b}$ \\
\hline Flow behavior index & $0.517 \pm 0.03^{\mathrm{a}}$ & $0.467 \pm 0.04 b^{c}$ & $0.443 \pm 0.05^{\mathrm{c}}$ & $0.502 \pm 0.02^{\mathrm{ab}}$ & $0.489 \pm 0.06^{\mathrm{ab}}$ & $0.461 \pm 0.04^{\mathrm{bc}}$ \\
\hline $\begin{array}{l}\text { Consistency coefficient } \\
\text { (mPas) }\end{array}$ & $304.33 \pm 1.34^{\mathrm{e}}$ & $328.99 \pm 0.02^{\mathrm{c}}$ & $375.63 \pm 2.74^{\mathrm{a}}$ & $314.86 \pm 2.28^{\mathrm{d}}$ & $316.25 \pm 1.50^{\mathrm{d}}$ & $350.29 \pm 0.52^{\mathrm{b}}$ \\
\hline $\begin{array}{l}\text { Total phenolic content } \\
\text { (mg GAE/100g) }\end{array}$ & $41.39 \pm 2.61^{\mathrm{c}}$ & $64.06 \pm 2.94^{\mathrm{a}}$ & $54.14 \pm 3.86^{\mathrm{b}}$ & $37.71 \pm 3.29^{c}$ & $52.98 \pm 2.02^{\mathrm{b}}$ & $42.96 \pm 3.04^{\mathrm{c}}$ \\
\hline $\begin{array}{l}\text { Radical scavenging } \\
\text { activity (RSA \%) }\end{array}$ & $53.12 \pm 1.88^{\mathrm{d}}$ & $87.84 \pm 3.16^{\mathrm{a}}$ & $76.23 \pm 3.77^{b}$ & $49.25 \pm 1.75^{\mathrm{d}}$ & $73.74 \pm 1.26^{\mathrm{b}}$ & $67.26 \pm 0.74^{\mathrm{c}}$ \\
\hline \multicolumn{7}{|l|}{ Ice milk or Ice cream: } \\
\hline Specific gravity (kg / L) & $0.589 \pm 0.03^{\mathrm{a}}$ & $0.582 \pm 0.01^{\mathrm{ab}}$ & $0.575 \pm 0.03^{\mathrm{ab}}$ & $0.555 \pm 0.01^{\mathrm{ab}}$ & $0.551 \pm 0.03^{\mathrm{ab}}$ & $0.542 \pm 0.01^{\mathrm{b}}$ \\
\hline Weight per gallon (kg) & $2.23 \pm 0.14^{\mathrm{a}}$ & $2.20 \pm 0.18^{\mathrm{a}}$ & $2.18 \pm 0.08^{\mathrm{a}}$ & $2.10 \pm 0.24^{\mathrm{a}}$ & $2.09 \pm 0.06^{\mathrm{a}}$ & $2.05 \pm 0.18^{\mathrm{a}}$ \\
\hline Overrun $(\%)$ & $91.57 \pm 0.86^{\mathrm{d}}$ & $93.11 \pm 2.28^{\mathrm{d}}$ & $95.19 \pm 3.73^{\mathrm{c}}$ & $95.34 \pm 1.74^{b c}$ & $97.18 \pm 1.86^{\mathrm{ab}}$ & $98.71 \pm 0.40^{\mathrm{a}}$ \\
\hline \multicolumn{7}{|l|}{ Meltdown rate (\%): } \\
\hline 5 min & $5.10 \pm 1.80^{\mathrm{a}}$ & $3.42 \pm 1.16^{\mathrm{b}}$ & $3.13 \pm 1.74^{\mathrm{b}}$ & $4.25 \pm 1.80^{\mathrm{ab}}$ & $4.10 \pm 1.50^{\mathrm{ab}}$ & $3.37 \pm 1.26^{\mathrm{b}}$ \\
\hline $10 \mathrm{~min}$ & $44.27 \pm 3.46^{\mathrm{a}}$ & $35.58 \pm 2.84^{b c}$ & $30.28 \pm 1.44^{\mathrm{d}}$ & $36.58 \pm 1.54^{\mathrm{b}}$ & $32.23 \pm 0.84^{\text {bcd }}$ & $31.25 \pm 2.66^{\mathrm{cd}}$ \\
\hline $15 \mathrm{~min}$ & $62.41 \pm 1.68^{\mathrm{a}}$ & $52.84 \pm 2.32^{\mathrm{bc}}$ & $50.27 \pm 1.46^{\mathrm{c}}$ & $57.84 \pm 0.66^{\mathrm{ab}}$ & $54.67 \pm 1.52^{\mathrm{bc}}$ & $51.27 \pm 2.02^{\mathrm{c}}$ \\
\hline $20 \mathrm{~min}$ & $91.27 \pm 1.74^{\mathrm{a}}$ & $80.27 \pm 1.50^{\mathrm{c}}$ & $75.34 \pm 2.32^{\mathrm{d}}$ & $84.64 \pm 1.22^{\mathrm{b}}$ & $83.17 \pm 2.80^{\mathrm{b}}$ & $78.84 \pm 0.86^{\mathrm{c}}$ \\
\hline
\end{tabular}

Mean $( \pm \mathrm{SD})$

${ }_{a, b, c}$ Values in the same row having different superscripts differ significantly $(p \leq 0.05)$

*See footnote Table (1). 
Amino acid profile of the formulas of ice milk and ice cream:

The amino acid profile of the ice milk (MIM, QIM, and CIM) and ice cream (MIC, QIC, and CIC) are presented in Tables (3). The results show that the total essential amino acids, values range between $47.65,41.40$ and $45.98 \mathrm{~g} / 100 \mathrm{~g}$ for ice milk (MIM, QIM, and CIM) and 47.99, 45.33 and $47.78 \mathrm{mg} / 100 \mathrm{~g}$ for ice cream (MIC, QIC, and CIC). Nutritionally, the recommended daily allowances (RDA) of some of the essential amino acids (valine, isoleucine and phenylalanine) were adequately met by the formulated food samples (FAO/WHO, 1991).

For the non-essential amino acids content of the ice cream samples range between 52.35, $\quad 58.60$ and $54.02 \mathrm{~g} / 100 \mathrm{~g}$ for ice milk (MIM, QIM and CIM) and $52.01,54.67$ and $52.22 \mathrm{mg} / 100 \mathrm{~g}$ for ice cream (MIC, QIC and CIC).

The leucine: isoleucine ratios of all treated chickpea seeds were typical, with an ideal ratio of 2.03:1 suggested by FAO/WHO (2011). Deosthale et al. (1970) showed that excess leucine in foods interfered with the utilization of isoleucine and lysine. Stratton et al. (2003) showed that the provision of nutritional supplements to malnourished patients to correct the protein-energy deficiencies reduces complications such as infections and wound breakdown by $70 \%$ and mortality by $40 \%$.

Table (3): Amino acid composition (g/100g protein) of ice milk and ice cream

\begin{tabular}{|c|c|c|c|c|c|c|c|c|}
\hline \multirow{3}{*}{ Amino acids } & \multicolumn{6}{|c|}{ Treatments* } & \multirow{3}{*}{$\begin{array}{l}\text { FAO/ } \\
\text { WHO } \\
(\mathbf{1 9 9 1 )}\end{array}$} & \multirow{3}{*}{$\begin{array}{l}\text { Whole egg } \\
\text { (Oser, } \\
\text { 1959) }\end{array}$} \\
\hline & \multicolumn{3}{|c|}{ Ice milk } & \multicolumn{3}{|c|}{ Ice cream } & & \\
\hline & MIM & QIM & CIM & MIC & QIC & CIC & & \\
\hline \multicolumn{9}{|l|}{ Essential amino acids: } \\
\hline Histidine & $2.83^{\mathrm{c}}$ & $3.33^{\mathrm{a}}$ & $2.71^{\mathrm{de}}$ & $2.79^{\mathrm{cd}}$ & $2.98^{\mathrm{b}}$ & $2.65^{\mathrm{e}}$ & 1.90 & 2.40 \\
\hline Isoleucine & $4.84^{\mathrm{c}}$ & $3.43^{\mathrm{e}}$ & $4.58^{\mathrm{d}}$ & $4.99^{\mathrm{b}}$ & $4.54^{\mathrm{d}}$ & $5.15^{\mathrm{a}}$ & 2.80 & 6.60 \\
\hline Leucine & $8.60^{\mathrm{ab}}$ & $7.71^{\mathrm{c}}$ & $8.20^{\mathrm{b}}$ & $8.72^{\mathrm{a}}$ & $8.47^{\mathrm{ab}}$ & $8.74^{\mathrm{a}}$ & 6.60 & 8.80 \\
\hline Lysine & $8.23^{\mathrm{a}}$ & $6.61^{\mathrm{c}}$ & $6.31^{\mathrm{d}}$ & $8.12^{\mathrm{a}}$ & $7.06^{\mathrm{b}}$ & $6.92^{\mathrm{b}}$ & 5.80 & 6.40 \\
\hline Methionine + Cystine & $2.76^{\mathrm{cd}}$ & $2.61^{\mathrm{d}}$ & $4.28^{\mathrm{a}}$ & $2.85^{\mathrm{c}}$ & $2.92^{\mathrm{c}}$ & $3.79^{\mathrm{b}}$ & 2.30 & 5.48 \\
\hline $\begin{array}{l}\text { Phenylalanine }+ \\
\text { Tyrosine }\end{array}$ & $9.26^{\mathrm{a}}$ & $7.96^{\mathrm{c}}$ & $9.34^{\mathrm{a}}$ & $9.25^{\mathrm{a}}$ & $8.54^{\mathrm{b}}$ & $9.26^{\mathrm{a}}$ & 6.30 & 10.08 \\
\hline Threonine & $4.42^{\mathrm{a}}$ & $4.41^{\mathrm{a}}$ & $4.18^{\mathrm{a}}$ & $4.40^{\mathrm{a}}$ & $4.36^{\mathrm{a}}$ & $4.24^{\mathrm{a}}$ & 3.40 & 4.98 \\
\hline Tryptophan & $1.26^{\mathrm{a}}$ & $0.85^{\mathrm{d}}$ & $1.05^{\mathrm{c}}$ & $1.27^{\mathrm{a}}$ & $1.09^{c}$ & $1.19^{\mathrm{b}}$ & 1.10 & 1.65 \\
\hline Valine & $5.44^{\mathrm{c}}$ & $4.50^{\mathrm{d}}$ & $5.34^{\mathrm{c}}$ & $5.59^{\mathrm{b}}$ & $5.38^{\mathrm{c}}$ & $5.84^{\mathrm{a}}$ & 3.5 & 7.42 \\
\hline Total EAA & $47.65^{\mathrm{a}}$ & $41.40^{\mathrm{c}}$ & $45.98^{\mathrm{b}}$ & $47.99^{\mathrm{a}}$ & $45.33^{\mathrm{b}}$ & $47.78^{\mathrm{a}}$ & 33.70 & \\
\hline \multicolumn{9}{|c|}{ Non-essential amino acids } \\
\hline Alanine & $3.30^{\mathrm{d}}$ & $4.78^{\mathrm{a}}$ & $4.33^{b}$ & $3.30^{\mathrm{d}}$ & $4.07 \mathrm{~b}^{\mathrm{c}}$ & $3.82^{\mathrm{c}}$ & & \\
\hline Arginine & $3.36^{\mathrm{d}}$ & $9.60^{\mathrm{a}}$ & $7.00^{\mathrm{b}}$ & $3.38^{\mathrm{d}}$ & $6.68^{\mathrm{b}}$ & $5.27^{\mathrm{c}}$ & & 6.56 \\
\hline Aspartic & $7.57^{\mathrm{c}}$ & $10.57^{\mathrm{a}}$ & $7.92^{c}$ & $7.51^{\mathrm{c}}$ & $8.99^{\mathrm{b}}$ & $7.59^{c}$ & & \\
\hline Glutamic & $21.83^{\mathrm{a}}$ & $17.13^{\mathrm{d}}$ & $19.16^{\mathrm{bc}}$ & $21.52^{\mathrm{a}}$ & $18.47^{\mathrm{c}}$ & $19.55^{\mathrm{b}}$ & & \\
\hline Glycine & $1.89^{\mathrm{e}}$ & $5.83^{\mathrm{a}}$ & $3.58^{\mathrm{c}}$ & $1.91^{\mathrm{e}}$ & $4.01^{\mathrm{b}}$ & $2.81^{\mathrm{d}}$ & & \\
\hline Proline & $9.46^{\mathrm{a}}$ & $4.91^{\mathrm{e}}$ & $5.99^{\mathrm{d}}$ & $9.42^{\mathrm{a}}$ & $6.97^{\mathrm{c}}$ & $7.57^{\mathrm{b}}$ & & \\
\hline Serine & $4.95^{\mathrm{b}}$ & $5.77^{\mathrm{a}}$ & $6.03^{\mathrm{a}}$ & $4.98^{\mathrm{b}}$ & $5.48^{\mathrm{ab}}$ & $5.61^{\mathrm{ab}}$ & & \\
\hline Total NEAAs & $52.35^{\mathrm{c}}$ & $58.60^{\mathrm{a}}$ & $54.02^{b}$ & $52.01^{\mathrm{c}}$ & $54.67^{b}$ & $52.22^{\mathrm{c}}$ & & \\
\hline $\begin{array}{l}\text { Leucine/isoleucine } \\
\text { ratio }\end{array}$ & $1.78^{c}$ & $2.24^{\mathrm{a}}$ & $1.79^{c}$ & $1.75^{\mathrm{cd}}$ & $1.87^{\mathrm{b}}$ & $1.70^{\mathrm{d}}$ & 2.36 & 1.33 \\
\hline
\end{tabular}

${ }^{a, b, c}$ Values in the same row having different superscripts differ significantly $(p \leq 0.05)$.

*See footnote Table (1).

Nutritional quality of the formulas of ice milk and ice cream:

Chemical Score (CS) estimates the amount of protein required to provide the minimal essential amino acids (EAA) pattern for adults, which was re-defined by FAO (Food and Agriculture Organization) in report $\mathrm{FAO} / \mathrm{WHO}$ (2011). Based on CS, the sequence of limiting amino acids and the protein score were determined for all the samples (Table 4). The protein score (SC) of ice milk MIM, QIM and CIM, was 81.69, 76.93 and $90.57 \%$, and ice cream MIC, QIC and CIC, range between $84.10,86.31$ and $88.65 \%$, respectively.
The chemical score of ice milk and ice cream protein is up to 70 , which makes it comparable to egg white (Friedman, 1996). Treatments of ice cream prepared by replacing fresh milk with quinoa and chia flour can be used to enrich products in the limiting amino acids. The results of nutritional quality of the ice cream (Table 4). The nutritional value of a protein may be estimated by calculating the values of protein efficiency ratio (PER). This calculation is based on the concentration of either leucine and proline (PER1); leucine and tyrosine (PER2); or methionine, leucine, histidine, and tyrosine (PER3). Usually, PER values 
higher than 2 indicate the high quality of a protein. PER values calculated for ice cream CIC, QIC and MIC and ice milk CIM, QIM and MIM, respectively indicated good quality of the protein (Mir et al., 2019). The essential amino acid indices (EAAIs) of the ice milk (MIM, QIM and CIM) and ice cream (MIC, QIC and CIC) samples were 81.45, 79.38, 85.68, 82.12, 83.96 and 86.28 respectively; while that of the biological values (BV) were $77.08 \%$ for the MIM, Vะ.^r\% QIM, 81.69\% CIM, 77.81\% MIC, 79.81\% QIC and 82.35\% CIC sample. Generally, a protein material is said to be of good nutritional quality when its biological values (BV) is high (70-100\%) and also when the essential amino acid index (EAAI) is above $90 \%$ and to be useful as food when the values is around $80 \%$ and to be inadequate for food material when below 70\% (Oser, 1959). For human and animal nutrition the quality of protein is determined by its biological value (BV)، which serves as an indicator of protein intake by relating nitrogen uptake to nitrogen excretion. The highest values $(\mathrm{p} \leq 0.05)$ of $\mathrm{BV}$ correspond to proteins of whole egg $(93.7 \%)$ and cow milk (84.5\%) (Friedman, 1996). The protein of quinoa has a $\mathrm{BV}$ of $83 \%$, which is higher $(\mathrm{p} \leq 0.05)$ than that of fish $(76 \%)$, beef $(74.3 \%)$, soybean $(72.8 \%)$, wheat $(64 \%)$, rice $(64 \%)$ and corn $(60 \%)$ proteins (James, 2009). In comparison, the BV and EAAI values in the present study were quite high relatively to the values reported by the Oser (1959). The same trend was observed for EAAI, PER, and BV indexes, which are commonly used to estimate the quality of food proteins. The Nutritional Index (NI), which is affected by the amount of protein and the EAA ratio, ice milk (MIM, QIM and CIM) and ice cream (MIC, QIC and CIC) samples were $2.23,0.95,2.18,2.19,1.37$ and 2.21 , respectively.

Table (4): Nutritional characteristics of the ice milk and ice cream

\begin{tabular}{|c|c|c|c|c|c|c|}
\hline \multirow{3}{*}{ Parameter } & \multicolumn{6}{|c|}{ Treatments* } \\
\hline & \multicolumn{3}{|c|}{ Ice milk } & \multicolumn{3}{|c|}{ Ice cream } \\
\hline & MIM & QIM & CIM & MIC & QIC & CIC \\
\hline \multicolumn{7}{|c|}{ Limiting EAA: } \\
\hline First & Tryptophan & Tryptophan & Tryptophan & Tryptophan & Tryptophan & Tryptophan \\
\hline Second & $\begin{array}{c}\text { Methionine + } \\
\text { Cystine }\end{array}$ & $\begin{array}{c}\text { Methionine + } \\
\text { Cystine }\end{array}$ & Histidine & $\begin{array}{c}\text { Methionine + } \\
\text { Cystine }\end{array}$ & $\begin{array}{c}\text { Methionine + } \\
\text { Cystine }\end{array}$ & Histidine \\
\hline CS\% & $81.69^{\mathrm{e}}$ & $76.93^{\mathrm{f}}$ & $90.57^{\mathrm{a}}$ & $84.10^{\mathrm{d}}$ & $86.31^{\mathrm{c}}$ & $88.65^{b}$ \\
\hline EAAI & $81.45^{\mathrm{c}}$ & $79.38^{\mathrm{d}}$ & $85.68^{\mathrm{a}}$ & $82.12^{\mathrm{c}}$ & $83.96^{\mathrm{b}}$ & $86.28^{\mathrm{a}}$ \\
\hline PER1 & $2.80^{\mathrm{c}}$ & $3.97^{\mathrm{b}}$ & $4.14^{\mathrm{ab}}$ & $4.22^{\mathrm{a}}$ & $4.22^{\mathrm{a}}$ & $4.32^{\mathrm{a}}$ \\
\hline PER2 & $2.96^{\mathrm{e}}$ & $3.59^{\mathrm{d}}$ & $3.73^{\mathrm{c}}$ & $3.95^{\mathrm{ab}}$ & $3.89^{\mathrm{b}}$ & $3.97^{\mathrm{a}}$ \\
\hline PER3 & $2.10^{\mathrm{c}}$ & $5.97^{\mathrm{ab}}$ & $5.70^{\mathrm{b}}$ & $5.83^{\mathrm{ab}}$ & $6.14^{\mathrm{a}}$ & $6.01^{\mathrm{ab}}$ \\
\hline BV\% & $77.08^{\mathrm{c}}$ & $74.82^{\mathrm{d}}$ & $81.69^{\mathrm{a}}$ & $77.81^{\mathrm{c}}$ & $79.81^{\mathrm{b}}$ & $82.35^{\mathrm{a}}$ \\
\hline NPU & $73.22^{\mathrm{e}}$ & $71.08^{\mathrm{f}}$ & $77.61^{\mathrm{b}}$ & $73.92^{\mathrm{d}}$ & $75.82^{\mathrm{c}}$ & $78.23^{\mathrm{a}}$ \\
\hline NI & $2.23^{\mathrm{a}}$ & $0.95^{\mathrm{c}}$ & $2.18^{\mathrm{a}}$ & $2.19^{\mathrm{a}}$ & $1.37^{\mathrm{b}}$ & $2.21^{\mathrm{a}}$ \\
\hline
\end{tabular}

a,b,c Values in the same row having different superscripts differ significantly $(\mathrm{p} \leq 0.05)$.

*See footnote Table (1).

\section{Fatty Acid Profile:}

The fatty acid composition of the ice cream was showed in Table (5). In ice milk MIM, QIM and CIM the content of saturated fatty acids (SFA) was 81.40, 67.06 and $17.61 \%$, respectively and ice cream MIC, QIC and CIC were 80.27, 76.30 and 67.25\%, respectively.

The content of monounsaturated fatty acids (MUFA) in ice milk MIM, QIM and CIM, 16.21, 19.08 and $4.45 \%$, respectively and ice cream MIC, QIC and CIC, 16.83, 17.60 and $14.34 \%$, respectively. The content of polyunsaturated fatty acids (PUFA n-6) in ice milk MIM, QIM and CIM, 1.90, 11.59 and 18.39\%, respectively and ice cream MIC, QIC and CIC, 2.39, 5.04 and $5.78 \%$, respectively. The content of polyunsaturated fatty acids (PUFA n-3) in ice milk MIM, QIM and CIM, 0.18, 1.77 and 59.39\%, and ice cream MIC, QIC and CIC, 0.44, 0.90 and $12.40 \%$, respectively. The CIM and QIC samples had significantly $\mathrm{p} \leq 0.05$ higher content of PUFA n-3 and PUFA n-6 than the QIM, QIC, MIC and MIM. The content of $\alpha$-linolenic acid in the ice cream had been rising according to the addition of chia flour. Also, there was observed a change in the ratio of polyunsaturated fatty acids (n-6) to polyunsaturated fatty acids (n-3). For the ice milk MIM, QIM and CIM sample the ratio were $6.42: 1,6.07: 1$ and $0.31: 1$ respectively, whereas in case of ice cream MIC, QIC and CIC were 5.24:1, 4.49:1 and 0.58:1 respectively. The high content of $n-3$ fatty acids in the diet provides many health benefits. It is essential for proper brain functions and has beneficial effects in cardiovascular diseases and in prevention of arthritis (Pizarro et al., 2015).

\section{Health-related indicators:}

The indices of atherogenicity (IA) and thrombogenicity (IT) and the $n 6 / \mathrm{n} 3$ ratio in ice cream samples, calculated on the base of the fatty acid contents, are presented in Table (5). The data show that the ice milk CIM and QIM and has generally better health-related indicators than ice cream CIC and QIC. Noticeable changes were found in the dynamics of IA and IT. The ratio of essential fatty acids (n6/n3) in ice milk prepared by replacing fresh milk with chia flour (CIM) is also lower, therefore in the CIM and CIC the effect of chia flour on $\mathrm{n} 6 / \mathrm{n} 3$ can be considered 
positive. It follows ice cream prepared by replacing fresh milk with quinoa flour than control ice cream (MIC) and control ice milk MIM. Moreover، ice milk and ice cream prepared by replacing fresh milk with chia and quinoa flour tends to be a beneficial to human health due to its low AI, TI and suitable n-6/n-3 ratio. But, Desaturase activity (DA) have close values between all treatments. Haug et al. (2007) and Tsiplakou and Zervas (2008) found the camel milk tends to be a beneficial to human health due to its low AI and suitable n-6/n-3 ratio. Yang et al. (2018) reported that the camel milk is likely to have a beneficial fatty acid profile due to its low AI and n-6/n3 ratio. The low n-6/n-3 ratio may differentiate yak milk from buffalo and cow milk. Desaturase activity index (DA) for buffalo, camel, cow, goat and yak milk samples was $0.29,0.39,0.29,0.34$ and 0.30 , respectively. Taking into account a negative role of the $\mathrm{C} 12: 0, \mathrm{C} 14: 0$, and $\mathrm{C} 16: 0$ acids, proposed atherogenic indices (AI) and thrombogenic indices (TI). Based on $\mathrm{AI}$ and $\mathrm{TI}$ values conclusions may be drawn concerning fat quality from the point of view of human diet (Ulbricht and Southgate, 1991). The healthpromoting index (HPI) is the inverse of the IA. It is currently mainly used in research on dairy products such as milk and cheese (Chen et al., 2004). Detailed information about the literature related to the HPI values range from 0.16 to 0.68 . Dairy products with a high HPI value are assumed to be more beneficial to human health (CIC, QIM, CIM and QIC).

Table (5): Fatty acids profile (g/100 g total FA methyl esters) of the ice milk and ice cream

\begin{tabular}{|c|c|c|c|c|c|c|}
\hline \multirow{3}{*}{ Fatty Acids } & \multicolumn{6}{|c|}{ Treatments* } \\
\hline & \multicolumn{3}{|c|}{ Ice milk } & \multicolumn{3}{|c|}{ Ice cream } \\
\hline & MIM & QIM & CIM & MIC & QIC & CIC \\
\hline Butyric (C4:0) & $9.23^{\mathrm{a}}$ & $4.31^{\mathrm{d}}$ & $0.74^{\mathrm{e}}$ & $5.98^{\mathrm{b}}$ & $5.19^{c}$ & $4.56^{\mathrm{d}}$ \\
\hline Caproic (C6:0) & $3.40^{\mathrm{a}}$ & $2.65^{\mathrm{c}}$ & $0.45^{\mathrm{d}}$ & $3.45^{\mathrm{a}}$ & $3.19^{\mathrm{b}}$ & $2.81^{\mathrm{c}}$ \\
\hline Caprylic (C8:0) & $1.70^{\mathrm{c}}$ & $1.52^{\mathrm{e}}$ & $0.26^{\mathrm{f}}$ & $1.94^{\mathrm{a}}$ & $1.83^{\mathrm{b}}$ & $1.61^{\mathrm{d}}$ \\
\hline Capric (C10:0) & $3.35^{\mathrm{b}}$ & $3.31^{\mathrm{b}}$ & $0.57^{\mathrm{c}}$ & $3.98^{\mathrm{a}}$ & $3.99^{\mathrm{a}}$ & $3.51^{\mathrm{b}}$ \\
\hline Undecanoic (C11:0) & $0.08^{\mathrm{ab}}$ & $0.09^{\mathrm{ab}}$ & $0.01^{\mathrm{b}}$ & $0.10^{\mathrm{a}}$ & $0.10^{\mathrm{a}}$ & $0.09^{\mathrm{ab}}$ \\
\hline Lauric (C12:0) & $3.89^{\mathrm{b}}$ & $3.75^{\mathrm{b}}$ & $0.64^{\mathrm{c}}$ & $4.53^{\mathrm{a}}$ & $4.50^{\mathrm{a}}$ & $3.95^{\mathrm{b}}$ \\
\hline Tridecylic (C13:0) & $0.16^{\mathrm{bc}}$ & $0.21^{\mathrm{a}}$ & $0.02^{\mathrm{d}}$ & $0.17^{\mathrm{bc}}$ & $0.18^{\mathrm{ab}}$ & $0.14^{\mathrm{c}}$ \\
\hline Myristic (C14:0) & $13.80^{\mathrm{a}}$ & $11.02^{\mathrm{c}}$ & $1.92^{\mathrm{d}}$ & $14.09^{\mathrm{a}}$ & $13.25^{\mathrm{ab}}$ & $11.64^{\mathrm{bc}}$ \\
\hline Pentadecaenoic (C15:0) & $1.43^{\mathrm{ab}}$ & $1.36^{\mathrm{b}}$ & $0.21^{\mathrm{d}}$ & $1.45^{\mathrm{a}}$ & $1.41^{\mathrm{ab}}$ & $1.18^{\mathrm{c}}$ \\
\hline Palmitic (C16:0) & $37.89^{\mathrm{a}}$ & $30.90^{\mathrm{b}}$ & $11.49^{\mathrm{c}}$ & $37.98^{\mathrm{a}}$ & $35.70^{\mathrm{a}}$ & $32.29^{\mathrm{b}}$ \\
\hline Margaric (C17:0) & $0.48^{\mathrm{ab}}$ & $0.44^{\mathrm{bc}}$ & $0.11^{\mathrm{d}}$ & $0.50^{\mathrm{a}}$ & $0.48^{\mathrm{ab}}$ & $0.42^{\mathrm{c}}$ \\
\hline Stearic (C18:0) & $5.76^{\mathrm{a}}$ & $4.70^{\mathrm{d}}$ & $1.03^{\mathrm{e}}$ & $5.84^{\mathrm{a}}$ & $5.51^{\mathrm{b}}$ & $4.85^{\mathrm{c}}$ \\
\hline Arachidic (C:20) & $0.23^{\mathrm{ab}}$ & $0.26^{\mathrm{a}}$ & $0.16^{\mathrm{b}}$ & $0.21^{\mathrm{ab}}$ & $0.22^{\mathrm{ab}}$ & $0.19^{\mathrm{ab}}$ \\
\hline Lignoceric (C24:0) & N.D. & $2.54^{\mathrm{a}}$ & N.D. & $0.06^{\mathrm{c}}$ & $0.75^{\mathrm{b}}$ & N.D. \\
\hline SFA & $81.40^{\mathrm{a}}$ & $67.06^{\mathrm{c}}$ & $17.61^{\mathrm{d}}$ & $80.27^{\mathrm{a}}$ & $76.30^{\mathrm{b}}$ & $67.25^{\mathrm{c}}$ \\
\hline Myristoleic (C14:1n9) & $1.65^{\mathrm{b}}$ & $1.51^{\mathrm{c}}$ & $0.26^{\mathrm{d}}$ & $1.86^{\mathrm{a}}$ & $1.82^{\mathrm{a}}$ & $1.60^{\mathrm{b}}$ \\
\hline Palmitoleic (C16:1n9) & $2.45^{\mathrm{a}}$ & $1.56^{\mathrm{e}}$ & $0.30^{\mathrm{a}}$ & $2.08^{\mathrm{b}}$ & $1.79^{\mathrm{c}}$ & $1.56^{\mathrm{d}}$ \\
\hline Heptadecenoic (C17:1) & $0.28^{\mathrm{a}}$ & $0.21^{\mathrm{c}}$ & N.D. & $0.27^{\mathrm{ab}}$ & $0.25^{\mathrm{abc}}$ & $0.23^{\mathrm{bc}}$ \\
\hline Elaidic (C18:1n9t) & $0.42^{\mathrm{c}}$ & $0.87^{\mathrm{a}}$ & $0.12^{\mathrm{d}}$ & $0.77^{\mathrm{b}}$ & $0.91^{\mathrm{a}}$ & $0.77^{\mathrm{b}}$ \\
\hline 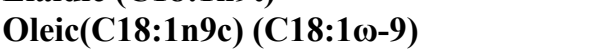 & $11.19^{\mathrm{d}}$ & $14.37^{\mathrm{a}}$ & $3.66^{\mathrm{f}}$ & $11.58^{\mathrm{c}}$ & $12.41^{\mathrm{b}}$ & $10.05^{\mathrm{e}}$ \\
\hline Vaccenic (C18:1n7) & $0.16^{\mathrm{a}}$ & N.D. & N.D. & $0.16^{\mathrm{a}}$ & $0.15^{\mathrm{a}}$ & $0.13^{\mathrm{a}}$ \\
\hline Eicosenoic (C20:1n9) & N.D. & $0.26^{\mathrm{a}}$ & N.D. & N.D. & $0.07^{\mathrm{b}}$ & N.D. \\
\hline Erucic $(C 22: 1 n 9)$ & N.D. & $0.29^{\mathrm{a}}$ & N.D. & $0.05^{\mathrm{c}}$ & $0.12^{\mathrm{b}}$ & N.D. \\
\hline Nervonic (C24:1) & $0.06^{\mathrm{a}}$ & N.D. & N.D. & $0.06^{\mathrm{a}}$ & $0.06^{\mathrm{a}}$ & N.D. \\
\hline MUFA & $16.21^{\mathrm{d}}$ & $19.08^{\mathrm{a}}$ & $4.35^{\mathrm{f}}$ & $16.83^{\mathrm{c}}$ & $17.60^{\mathrm{b}}$ & $14.34^{\mathrm{e}}$ \\
\hline Linolelaidic (C18:2n6t) & $0.22^{\mathrm{a}}$ & $0.21^{\mathrm{a}}$ & $0.04^{\mathrm{b}}$ & $0.26^{\mathrm{a}}$ & $0.25^{\mathrm{a}}$ & $0.22^{\mathrm{a}}$ \\
\hline Linoleic (C18:2 $\omega-6)$ & $1.24^{\mathrm{f}}$ & $10.91^{\mathrm{b}}$ & $17.90^{\mathrm{a}}$ & $1.58^{\mathrm{e}}$ & $4.28^{\mathrm{d}}$ & $4.99^{c}$ \\
\hline Conjugated linoleic (cis-9, trans-11) (C18:2n6) & $0.33^{\mathrm{a}}$ & $0.31^{\mathrm{a}}$ & $0.05^{\mathrm{b}}$ & $0.38^{\mathrm{a}}$ & $0.38^{\mathrm{a}}$ & $0.33^{\mathrm{a}}$ \\
\hline$\gamma$-Linolenic (C18:3n6) & N.D. & N.D. & $0.27^{\mathrm{a}}$ & N.D. & N.D. & $0.05^{\mathrm{b}}$ \\
\hline Arachidonic (C20:4 $\omega-6)(\mathrm{C} 20: 4 n 6)$ & $0.12^{\mathrm{b}}$ & $0.16^{\mathrm{ab}}$ & $0.14^{\mathrm{ab}}$ & $0.18^{\mathrm{a}}$ & $0.19^{\mathrm{a}}$ & $0.19^{\mathrm{a}}$ \\
\hline PUFA n-6 & $1.90^{\mathrm{f}}$ & $11.59^{\mathrm{b}}$ & $18.39^{\mathrm{a}}$ & $2.39^{\mathrm{e}}$ & $5.09^{\mathrm{d}}$ & $5.78^{\mathrm{c}}$ \\
\hline$\alpha$-Linolenic acid (C18:3 $\omega-3)(\mathrm{C} 18: 3 n 3)$ & $0.18^{\mathrm{e}}$ & $1.77^{\mathrm{c}}$ & $59.38^{\mathrm{a}}$ & $0.30^{\mathrm{e}}$ & $0.74^{\mathrm{d}}$ & $12.25^{\mathrm{b}}$ \\
\hline 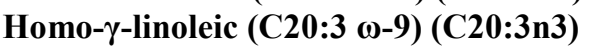 & N.D. & N.D. & N.D. & $0.09^{\mathrm{a}}$ & $0.09^{\mathrm{a}}$ & $0.08^{\mathrm{a}}$ \\
\hline Docosahexaenoic acid (DHA) (C22:6 $\omega-3)$ & N.D. & N.D. & N.D. & $0.06^{\mathrm{a}}$ & $0.07^{\mathrm{a}}$ & $0.07^{\mathrm{a}}$ \\
\hline PUFA n-3 & $0.18^{\mathrm{f}}$ & $1.77^{\mathrm{c}}$ & $59.39^{\mathrm{a}}$ & $0.44^{\mathrm{e}}$ & $0.90^{\mathrm{d}}$ & $12.40^{\mathrm{b}}$ \\
\hline PUFA n-6/ PUFA n-3 & $10.42^{\mathrm{a}}$ & $6.55^{\mathrm{b}}$ & $0.31^{\mathrm{f}}$ & $5.36^{\mathrm{d}}$ & $5.64^{\mathrm{c}}$ & $0.47^{\mathrm{e}}$ \\
\hline Atherogenicity Index (AI) & $5.92^{\mathrm{a}}$ & $2.24^{\mathrm{d}}$ & $0.07^{\mathrm{e}}$ & $5.20^{\mathrm{b}}$ & $3.83^{\mathrm{c}}$ & $5.92^{\mathrm{a}}$ \\
\hline Thrombogenicity Index (TI) & $5.30^{\mathrm{a}}$ & $2.43^{\mathrm{d}}$ & $0.24^{\mathrm{e}}$ & $5.03^{\mathrm{b}}$ & $3.95^{\mathrm{c}}$ & $5.30^{\mathrm{a}}$ \\
\hline Desaturase activity (DA) & $0.21^{\mathrm{a}}$ & $0.27^{\mathrm{a}}$ & $0.23^{\mathrm{a}}$ & $0.21^{\mathrm{a}}$ & $0.23^{\mathrm{a}}$ & $0.21^{\mathrm{a}}$ \\
\hline Health Promoting Index (HPI) & $0.19^{\mathrm{d}}$ & $0.41^{\mathrm{b}}$ & $4.15^{\mathrm{a}}$ & $0.20^{\mathrm{cd}}$ & $0.25^{\mathrm{c}}$ & $0.39^{\mathrm{b}}$ \\
\hline
\end{tabular}




\section{Colour properties:}

The colour of ice cream has a remarkable influence on consumer acceptance. According to the results obtained for the colour parameters (Table 6) significant changes $(p \leq 0.05)$ were observed with the addition of different flour of quinoa and chia. A pronouncedly $(\mathrm{p} \leq .0 .05)$ decrease in the lightness $\left(\mathrm{L}^{*}\right.$, scale ranges from 0 to 100 , from black to white) was observed with the increase of the amount of flour of quinoa and chia of ice milk (QIM and CIM)) and increase in the lightness $\mathrm{L}^{*}$ of ice cream (MIC, QIC and $\mathrm{CIC}$ ), respectively. This behaviour is related to an increase of the red colour (RI) and browning Index (BI) of the ice cream fortified by chia and quinoa ice milk CIM, QIM and ice cream CIC and QIC respectively, reducing the tendency to white visualized on the control ice cream and ice milk (MIC and MIM). The $\Delta \mathrm{E}$ increased for the ice cream samples containing chia flour (CIM and CIC) then treatments with quinoa flour (QIM and QIC). Lightness was then suggested as the major contributing factor to whiteness. Chroma $\left(\mathrm{C}^{*}\right)$ increased in ice milk samples CIM and QIM, indicating that the colour of ice cream became more intensem, it followed ice cream samples CIC and QIC. Differences in the colour parameters of ice cream can be attributed to different content of the flour quinoa and chia. Regarding measurements made in ice cream, it was found that the anthocyanin (colour) content in the ice cream with different amounts of quinoa and chia flour showing colours degree of light yellowish whites and slightly yellowish whites when added to the ice cream fortified by quinoa and chia flour (CIM, QIM, CIC and QIC, respectively. This reason has resulted from increase of browning Index (BI) for ice cream containing more quantities of chia and quinoa flour in ice milk (CIM QIM and QIM) then less quantities in ice cream (CIC and QIC) compared with control (MIM and MIC). Browning index is a parameter in measuring amounts of colour parameters and shows the amount of color change towards brown of chia seed flour (Hatamian et al., 2020). Table (6) shows were also the colour parameters $\left(\mathrm{L}^{*}, \mathrm{a}^{*}, \mathrm{~b}^{*}, \mathrm{~h}_{\mathrm{ab}}\right.$ and $\left.\mathrm{C}_{\mathrm{ab}}\right)$. The difference in lightness $\left(\mathrm{L}^{*}\right)$ was statistically significant $(p \leq 0.05)$ among white flours and red and black ones, for the latest in fact were recorded the lowest values ( $p$ $\leq 0.05)$. The red-green coordinate $\left(\mathrm{a}^{*}\right)$ and yellow-blue coordinate $\left(b^{*}\right)$ were significantly higher $(p \leq 0.05)$ in CIM, QIM, CIC, QIC and lower $(\mathrm{p} \leq 0.05)$ in MIC and MIM. Consequentially, the same statistically differences were showed in Chroma $\left(\mathrm{C}_{\mathrm{ab}}\right)$, for which CIM, QIM, CIC and QIC; concerning hue values $\left(\mathrm{h}_{\mathrm{ab}}\right)$, higher degrees $(\mathrm{p} \leq 0.05)$ were recorded for MIM (73.89) while lower ones for CIM (-86.97). The obtained results suggest therefore, that the incorporation of a certain quantity of these flours (chia and quinoa) may change appearance of target systems. Pellegrini et al. (2018) reported that the quantities of flours obtained from quinoa (Chenopodium quinoa Willd) seeds should be chosen considering consumer preferences and product marketability.

Table (6): Colour properties of the ice milk and ice cream

\begin{tabular}{|c|c|c|c|c|c|c|}
\hline \multirow{3}{*}{ Parameter } & \multicolumn{6}{|c|}{ Treatments* } \\
\hline & \multicolumn{3}{|c|}{ Ice milk } & \multicolumn{3}{|c|}{ Ice cream } \\
\hline & MIM & QIM & CIM & MIC & QIC & CIC \\
\hline $\mathbf{L}^{*}$ & $83.71 \pm 0.18^{\mathrm{ab}}$ & $76.14 \pm 0.63^{c}$ & $69.58 \pm 2.36^{d}$ & $86.78 \pm 1.87^{\mathrm{a}}$ & $81.24 \pm 1.90^{\mathrm{b}}$ & $77.11 \pm 0.64^{\mathrm{c}}$ \\
\hline$a^{*}$ & $-2.29 \pm 0.88^{\mathrm{bc}}$ & $-2.23 \pm 0.20^{\mathrm{bc}}$ & $-0.62 \pm 0.08^{\mathrm{a}}$ & $-2.55 \pm 0.16^{\mathrm{c}}$ & $-2.08 \pm 0.06^{\mathrm{b}}$ & $-0.87 \pm 0.08^{\mathrm{a}}$ \\
\hline $\mathbf{b}^{*}$ & $7.93 \pm 1.16^{\mathrm{c}}$ & $9.88 \pm 0.76^{\mathrm{b}}$ & $11.72 \pm 2.03^{\mathrm{a}}$ & $6.47 \pm 0.52^{\mathrm{d}}$ & $8.06 \pm 0.62^{\mathrm{c}}$ & $10.51 \pm 1.90^{\mathrm{ab}}$ \\
\hline$C^{*}$ & $8.25 \pm 1.22^{\mathrm{c}}$ & $10.13 \pm 1.12^{\mathrm{b}}$ & $11.74 \pm 1.36^{\mathrm{a}}$ & $6.95 \pm 0.88^{\mathrm{d}}$ & $8.32 \pm 0.58^{c}$ & $10.55 \pm 1.44^{\mathrm{b}}$ \\
\hline $\mathbf{h a b}^{\circ}$ & $-73.89 \pm 0.35^{\mathrm{b}}$ & $-77.28 \pm 0.84^{\mathrm{c}}$ & $-86.97 \pm 1.03^{\mathrm{d}}$ & $-68.49 \pm 1.63^{\mathrm{a}}$ & $-75.53 \pm 0.72^{\mathrm{bc}}$ & $-85.27 \pm 0.97^{\mathrm{C}}$ \\
\hline WI & $81.74 \pm 0.80^{\mathrm{b}}$ & $74.08 \pm 1.32^{\mathrm{d}}$ & $67.39 \pm 1.70^{\mathrm{e}}$ & $85.06 \pm 1.08^{\mathrm{a}}$ & $79.48 \pm 1.13^{\mathrm{c}}$ & $74.80 \pm 1.70^{\mathrm{d}}$ \\
\hline$\Delta \mathbf{E}$ & 0.00 & $7.82 \pm 0.58^{\mathrm{d}}$ & $14.72 \pm 1.12^{\mathrm{a}}$ & 0.00 & $5.78 \pm 0.38^{\mathrm{c}}$ & $10.61 \pm 0.82^{b}$ \\
\hline $\mathbf{R I}$ & $-0.29 \pm 0.08^{c}$ & $-0.23 \pm 0.04^{b}$ & $-0.05 \pm 0.04^{\mathrm{a}}$ & $-0.39 \pm 0.03^{\mathrm{d}}$ & $-0.26 \pm 0.10^{\mathrm{bc}}$ & $-0.08 \pm 0.02^{\mathrm{a}}$ \\
\hline BI & $7.59 \pm 1.02^{\mathrm{d}}$ & $11.24 \pm 1.40^{\mathrm{c}}$ & $17.14 \pm 1.96^{\mathrm{a}}$ & $5.33 \pm 1.08^{\mathrm{e}}$ & $8.20 \pm 1.84^{\mathrm{d}}$ & $13.30 \pm 1.44^{\mathrm{b}}$ \\
\hline
\end{tabular}

Mean $( \pm \mathrm{SD})$

${ }^{a, b, c}$ Values in the same row having different superscripts differ significantly $(\mathrm{p} \leq 0.05)$.

*See footnote Table (1).

\section{Sensory Characteristics:}

The differences in sensory properties of ice cream from different treatments are shown in Table (7). The ice cream (MIC, QIC and CIC) gained the highest scores for acceptability, rich and creamy taste. Milk fat has been recognized as an essential constituent for the formation and support of the structural characteristics of ice cream (Turgut and Cakmacki, 2009). This have been interconnected with milk fat functionality including fat destabilization, increased air incorporation and air cells stabilization, lubrication of oral tissue and improvement of mouth sensation
(Dresselhuis et al., 2008). The panelists observed that removing the fat from ice cream made it cooler and more watery body \& texture with few visible air bubbles. Adding quinoa flour significantly improved the body \& texture of ice cream and gained the highest $p \leq 0.05$ acceptability scores. This may be explained on the possible interactions between fibers, protein matrix and stabilizer which resulted in higher rheological characteristics of activity. Colour is an important parameter to the quality of food products because of its association with factors such as freshness, ripeness, desirability, and food safety. It is often a primary 
consideration for consumers when making purchasing decisions. All ice cream exhibited different colours of variable intensity according to the ingredient ratio used. The panelists described the colour of the resultant ice cream as new and unique. A physical property of ice cream has a major influence on the sensory quality in general, and texture assessment is viscosity. Sensory viscosity in the partially melted state is an important factor because it influences how a sample of ice cream reacts within a person's mouth. The resistance of an ice cream to the mechanical forces imparted by the tongue, upper palate and teeth will dictate the overall perception of ice cream texture (Akoh, 1998). Panelists found significant differences $(p \leq 0.05)$ among the samples (Table 7). Sensory judges perceived ice creams containing chia and quinoa flour to have the least viscosity and their differences were significantly important $(p \leq 0.05)$. If the effect of the flour type in the viscosity production was considered, it could be seen that (CIM and CIC) produced the highest ( $\mathrm{p} \leq$ $0.05)$ value of sensory viscosity, the difference with MIC and MIM was significant $(\mathrm{p} \leq 0.05)$. It was observed that there is a good correlation between the results of the sensory viscosity and instrumental viscosity (apparent and Plastic viscosity). As melting occurs within the mouth, large ice particles are momentarily left behind creating the distinct sensation of coldness (Bodyfelt et al., 1988). Chia and quinoa flour (CIM, CIC, QIM and QIC) produced the highest coldness in ice cream، respectively (Table 7). This is probably due to the role of viscosity. The firmness of ice cream is related to its structure. The air cells of ice cream structure are essentially spherical, although there is some distortion due to the formation of fat and ice crystals. The material surrounding these air cells is a non-Newtonian fluid containing clumps of fat (up to $80 \%$ ) and small ice crystals (Aime et al., 2001). Chia and quinoa flour produced the highest firmness in the products, respectively. These findings were predictable due to their viscosity. It was seen that the protein and fibers bind water, increase the viscosity and enhanced the firmness of ice creams. As it is shown in Table (7), panelists found significant difference for the degree of smoothness (coarseness) among the treatments $(\mathrm{p} \leq$
0.05). Ice milk prepared by replacing fresh milk with chia flour (CIM) produced the highest coarseness resulted the more amount chia flour used. All the samples had a desirable smoothness, which confirm that selected quinoa and chia flour act as suitable in term of smoothness. A smooth texture is an indicator of uniform small ice crystals and air cells and no detectable crystals (Abdullah et al., 2003).

The liquefying rate scores were significantly different $(\mathrm{p} \leq 0.05)$. The liquefying or melting rate was evaluated as intermediate that is acceptable (Table 7). If the product melts too fast, a messy situation ensues. A fast-melting product is undesirable as it tends to heat readily. However, a slow rate of melting can also be indicative of a defective ice cream (Goff and Hartel, 2013). Ice milk and ice cream containing chia flower had the highest $(p \leq 0.05)$ liquefying rate, while quinoa ice milk and ice cream had intermediate liquefying rate. Texture is directly related to the structure. Structure depends on the size, number and arrangement of air cells, ice crystals and fat clumps (Abdullah et al., 2003). The body and texture values were significantly different $(\mathrm{p} \leq 0.05)$. Samples with quinoa flour (QIC and QIM) acquired the best body and texture scores (Table 7), although the difference between MIM and MIC was not significant ( $p \geq 0.05$ ). On the contrary، CIM declined the body and texture scores of ice creams significantly $(\mathrm{p} \leq 0.05$ ). This can be related to the increase amount chia flour of ice cream. In this study، all the ice cream samples obtained body and texture scores better than average. The desired texture of an ice cream is smooth, creamy and homogeneous but the desired body should be firm with substantial feeling of solid matter within the foam (Goff and Hartel, 2013). The total acceptance of soft ice cream was assessed between 7.11 and 8.91, where the most acceptable ice cream was the sample containing quinoa flour QIC and QIM (Table 7). Total acceptance scores of all the samples were higher than the average value (7) in a 9point scale. Although significant differences were observed between the samples containing quinoa and chia flour. CIM decreased the overall acceptability of an ice cream.

Table (7): Sensory evaluation of the ice milk and ice cream

\begin{tabular}{|c|c|c|c|c|c|c|}
\hline \multirow{3}{*}{ Parameter } & \multicolumn{6}{|c|}{ Treatments* } \\
\hline & \multicolumn{3}{|c|}{ Ice milk } & \multicolumn{3}{|c|}{ Ice milk } \\
\hline & MIM & QIM & CIM & MIC & QIC & CIC \\
\hline Appearance (9) & $8.57 \pm 0.75^{b}$ & $8.19 \pm 0.12^{\mathrm{c}}$ & $7.56 \pm 0.30^{\mathrm{d}}$ & $8.91 \pm 0.08^{\mathrm{a}}$ & $8.56 \pm 0.32^{b}$ & $8.29 \pm 0.10^{\mathrm{bc}}$ \\
\hline Flavour (9) & $8.89 \pm 0.18^{\mathrm{a}}$ & $8.53 \pm 0.34^{\mathrm{a}}$ & $7.11 \pm 1.55^{\mathrm{b}}$ & $8.95 \pm 1.36^{\mathrm{a}}$ & $8.62 \pm 0.30^{\mathrm{a}}$ & $8.23 \pm 0.08^{\mathrm{ab}}$ \\
\hline Coldness (9) & $8.01 \pm 0.42^{\mathrm{c}}$ & $8.34 \pm 0.68^{\mathrm{bc}}$ & $8.93 \pm 0.06^{\mathrm{a}}$ & $8.13 \pm 0.02^{\mathrm{c}}$ & $8.29 \pm 0.48^{\mathrm{c}}$ & $8.71 \pm 0.58^{\mathrm{ab}}$ \\
\hline Firmness (9) & $8.24 \pm 1.08^{\mathrm{a}}$ & $8.46 \pm 0.92^{\mathrm{a}}$ & $8.89 \pm 0.22^{\mathrm{a}}$ & $8.38 \pm 0.06^{\mathrm{a}}$ & $8.31 \pm 0.38^{\mathrm{a}}$ & $8.76 \pm 0.12^{\mathrm{a}}$ \\
\hline Viscosity (9) & $8.07 \pm 0.14^{\mathrm{c}}$ & $8.68 \pm 0.04^{\mathrm{ab}}$ & $8.85 \pm 0.30^{\mathrm{a}}$ & $8.11 \pm 0.98^{\mathrm{bc}}$ & $8.38 \pm 1.04^{\mathrm{abc}}$ & $8.72 \pm 0.44^{\mathrm{a}}$ \\
\hline Smoothness (9) & $8.83 \pm 0.26^{\mathrm{a}}$ & $8.52 \pm 0.16^{\mathrm{b}}$ & $8.05 \pm 0.10^{\mathrm{c}}$ & $8.92 \pm 0.16^{\mathrm{a}}$ & $8.84 \pm 0.12^{\mathrm{a}}$ & $8.57 \pm 0.04^{\mathrm{b}}$ \\
\hline Liquefying (9) & $8.07 \pm 0.14^{\mathrm{c}}$ & $8.55 \pm 0.40^{\mathrm{b}}$ & $8.96 \pm 0.08^{\mathrm{a}}$ & $8.15 \pm 0.30^{c}$ & $8.51 \pm 0.22^{b}$ & $8.62 \pm 0.76^{\mathrm{ab}}$ \\
\hline Body and texture (9) & $8.62 \pm 0.44^{\mathrm{ab}}$ & $8.77 \pm 0.84^{\mathrm{a}}$ & $8.16 \pm 0.22^{\mathrm{b}}$ & $8.67 \pm 0.34^{\mathrm{ab}}$ & $8.96 \pm 0.08^{\mathrm{a}}$ & $8.87 \pm 1.04^{\mathrm{a}}$ \\
\hline Total acceptance (9) & $8.27 \pm 0.40^{\mathrm{c}}$ & $8.34 \pm 0.34^{\mathrm{bc}}$ & $7.11 \pm 0.22^{\mathrm{d}}$ & $8.84 \pm 0.72^{\mathrm{ab}}$ & $8.91 \pm 0.94^{\mathrm{a}}$ & $8.24 \pm 0.62^{\mathrm{c}}$ \\
\hline Total score $(81)$ & $75.57 \pm 2.14^{\mathrm{a}}$ & $76.38 \pm 2.04^{\mathrm{a}}$ & $73.62 \pm 2.12^{\mathrm{b}}$ & $77.06 \pm 2.10^{\mathrm{a}}$ & $77.38 \pm 1.46^{\mathrm{a}}$ & $77.01 \pm 1.31^{\mathrm{a}}$ \\
\hline
\end{tabular}




\section{CONCLUSION}

In conclusion, the current study has shown that the application of quinoa (QIM and QIC) and chia flour (CIC) flour has a positive impact on the production of ice milk and ice cream without impeding effects on the physicochemical characteristics and sensory properties of the final product. The results showed that completely replacing fresh milk with chia flour in ice milk resulted in a product with high rheological properties, but lower sensory properties as compared to the other samples. Whereas, when replacing fresh milk with quinoa flour in the ice milk and ice cream, it caused high sensory properties scores and lower rheological properties than samples containing chia flour.

\section{ACKNOWLEDGEMENTS}

The author would like to thank Dr. Abdelmoneim H. Ali, State Key Lab of Food Science and Technology, Jiangnan University, Wuxi, China; International Joint Research Laboratory for Lipid Nutrition and Safety, Collaborative Innovation Center of Food Safety and Quality Control in Jiangsu Province, School of Food Science and Technology, Jiangnan University, Wuxi, China and Department of Food Science, Faculty of Agriculture, Zagazig University, Zagazig, Egypt, for help with some chemical analyzes (amino acids and fatty acids profile) in China.

\section{REFERENCES}

Abdullah, M., S. Rehman, H. Zubair, H. M. Saeed, S. Kousar, and M. Shahid (2003). Effect of skim milk in soymilk blend on the quality of ice cream. Pakistan J. Nutri., 2(5): 305-311.

Adleman, R. and R. W. Hartel (2001). Lipid crystallization and its effect on the physical structure of ice cream. In: Garti, N., Sato, K. (eds) Crystallization processes in fats and lipid systems. Marcel Dekker, New York, pp 381427

Aime, D. B., S. D. Arntfield, L. J. Malcolmson and D. Ryland (2001). Textural analysis of fat reduced vanilla ice cream products. Food Res. Inter., 34(2-3): 237-246.

Akoh, C. C. (1998). Fat replacers. Food technology, 52(3): 47-53

Alfredo, V. O., R. R. Gabriel, C. G. Luis and B. A. David (2009). Physicochemical properties of a fibrous fraction from chia (Salvia hispanica L.). LWT-Food Sci. and Technol., 42(1): 168173.

Alsmeyer, H. R., A. E. Caningham and M. L. Happich (1974). Equation predict PER from amino acid analysis. Food Technol., 28: 34-40.

Alvarez-Jubete, L., H. Wijngaard, E. K. Arendt and E. Gallagher (2010). Polyphenol composition and in vitro antioxidant activity of amaranth, quinoa buckwheat and wheat as affected by sprouting and baking. Food Chemi., 119(2): $770-778$.

AOAC (2007). Official Methods of Analysis of the Association of Official Analytical Chemists. $18^{\text {th }}$ Ed., Association of Official Analytical Chemists, Washington, DC., USA.

BahramParvar, M., S. M. Razavi and M. H. Khodaparast (2010). Rheological characterization and sensory evaluation of a typical soft ice cream made with selected food hydrocolloids. Food Sci. and Technol. Inter., 16(1): 79-88.

Block, R.J. and H. H. Mitchell (1946). The Correlation of the amino acid composition of proteins with their nutritive value. Nutri. Abstracts and Reviews, 16(2): 249 - 278 .

Bodyfelt, F. W., J. Tobias and G. M. Trout (1988). The Sensory Evaluation of Dairy Products. Van Nostrand Reinhold. New York.

Burke, A. (1947). Practical Ice Cream Making. The Olsen Publishing Company, Milwauke. Wesconsin. U.S.A.

Capitani, M. I., V. Y. Ixtaina, S. M. Nolasco and M. C. Tomás (2013). Microstructure, chemical composition and mucilage exudation of chia (Salvia hispanica L.) nutlets from Argentina. J. of the Sci. of Food and Agri., 93(15): 38563862 .

Capitani, M. I., V. Spotorno, S. M. Nolasco and M. C. Tomás (2012). Physicochemical and functional characterization of by-products from chia (Salvia hispanica L.) seeds of Argentina. LWT-Food Sci. and Technol., 45(1): 94-102.

Chandan, R. C. and A. Kilara (2011). Dairy Ingredients for Food Processing. Blackwell Publishing Ltd. USA.

Chang, S. T. and W. A. Hayes (1978). The Biology and Cultivation of Edible Mushrooms. Academic Press. New York Academic, pp 137-165.

Chen, H. H., E. M. Chiu and J. R. Huang (1997). Color and gel $\square$ forming properties of horse mackerel (Trachurus japonicus) as related to washing conditions. J. Food Sci., 62(5): 985-991.

Chen, S., G. Bobe, S. Zimmerman, E. G. Hammond, C. M. Luhman, T. D. Boylston and D. C. Beitz (2004). Physical and sensory properties of dairy products from cows with various milk fatty acid compositions. J. Agri. and Food Chemi., 52(11): 3422-3428.

Coorey, R., A. Tjoe and V. Jayasena (2014). Gelling properties of chia seed and flour. J. Food Sci., 79(5): 859-866.

Deosthale, Y. G., V. S. Mohan and K. V. Rao (1970). Varietal differences in protein, lysine, and leucine content of grain sorghum. J. Agri. and Food Chemi., 18(4): 644-646.

Dresselhuis, D. M., E. H. A. De Hoog, M. C. Stuart, M. H. Vingerhoeds and G. A. Van Aken (2008). The occurrence of in-mouth coalescence of emulsion droplets in relation to perception of fat. Food Hydrocolloids, 22(6): 1170-1183.

Dubey, U. K. and C. H. White (1997). Ice cream shrinkage: A problem for the ice cream industry. J. Dairy Sci., 80(12): 3439-3444.

FAO/WHO, J. (1991). Protein Quality Evaluation. Report of Joint FAO/WHO Expert 
Consultation. FAO Food and Nutrition Paper 51.

FAO/WHO/UNU Expert Consultation (2011). Dietary Protein Quality Evaluation in Human Nutrition. FAO Food Nutrition, pp, 92, 1-66.

Folch, J., M. Lees and G. S. Stanley (1957). A simple method for the isolation and purification of total lipides from animal tissues. J. Biological Chemi., 226(1): 497-509.

Friedman, M. (1996). Nutritional value of proteins from different food sources. A review. J. Agri and Food Chemi., 44(1): 6-29.

Goff, H. D., and R. W. Hartel (2013). Ice Cream. $7^{\text {th }}$ Edition. Springer Science \& Business Media. Media New York.

Goff, H. D., E. Verespej and A. K. Smith (1999). A study of fat and air structures in ice cream. Inter. Dairy J., 9(11): 817-829.

Guzmán $\square$ González, M., F. Morais, M. Ramos and L. Amigo (1999). Influence of skimmed milk concentrate replacement by dry dairy products in a low fat set $\square$ type yoghurt model system. I: Use of whey protein concentrates, milk protein concentrates and skimmed milk powder. J. of the Sci. of Food and Agri., 79(8): 1117-1122.

Hartel, R. W. (2019). Crystallization in Foods. In: Handbook of Industrial Crystallization. $3^{\text {rd }} \mathrm{Ed}$. Cambridge University Press. pp. 460-478.

Hatamian, M., M. Noshad, S. Abdanan-Mehdizadeh and H. Barzegar (2020). Effect of roasting treatment on functional and antioxidant properties of chia seed flours. NFS J., 21: 1-8.

Haug, A., A. T. Høstmark and O. M. Harstad (2007). Bovine milk in human nutrition-a review. Lipids in Health and Disease, 6(1): 25.

Huppertz, T., M. A. Smiddy, H. D. Goff and A. L. Kelly (2011). Effects of high-pressure treatment of mix on ice cream manufacture. Inter. Dairy J., 21(9): 718-726.

Jaddu, S. and H.V. Yedida (2018). Chia seed: A magical medicine. J. Pharm Phyto, 7(2): 1320-1322.

James, L. E. A. (2009). Quinoa (Chenopodium quinoa Willd.): composition, chemistry, nutritional, and functional properties. Advances in Food and Nutri. Res., 58: 1-31.

Jeske, S., E. Zannini, K. M. Lynch, A. Coffey and E. K. Arendt (2018). Polyol-producing lactic acid bacteria isolated from sourdough and their application to reduce sugar in a quinoa-based milk substitute. Inter. J. Food Microbiol., 286: 31-36.

Kurek, M. A., S. Karp, J. Wyrwisz and Y. Niu (2018). Physicochemical properties of dietary fibers extracted from gluten-free sources: quinoa (Chenopodium quinoa), amaranth (Amaranthus caudatus) and millet (Panicum miliaceum). Food Hydrocolloids, 85: 321-330.

Mäkinen, O. E., T. Uniacke-Lowe, J. A. O'Mahony and E. K. Arendt (2015). Physicochemical and acid gelation properties of commercial UHT-treated plant-based milk substitutes and lactose free bovine milk. Food Chemi., 168: 630-638.
Mir, N. A., C. S. Riar and S. Singh (2019). Effect of pH and holding time on the characteristics of protein isolates from Chenopodium seeds and study of their amino acid profile and scoring. Food Chemi., 272:165-173.

Mitschka, P. (1982). Simple conversion of Brookfield R.V.T. readings into viscosity functions. Rheol. Acta, 21: 207-209.

Ohmes, R. L., R. T. Marshall and H. Heymann (1998). Sensory and physical properties of ice creams containing milk fat or fat replacers. J. Dairy Sci., 81(5): 1222-1228.

Olivos-Lugo, B. L., M. Á. Valdivia-López and A. Tecante (2010). Thermal and physicochemical properties and nutritional value of the protein fraction of Mexican chia seed (Salvia hispanica L.). Food Sci. and Technol. Inter., 16(1): 89-96.

Oser, B. L. (1959). An integrated essential amino acid index for predicting the biological value of proteins. Protein and Amino Acid Nutrition. New York: Academic Press. pp 281-295.

Palou, E., A. Lopez-Malo, G.V. Barbosa-Canovas, J. Welti-Chanes and B.G. Swanson (1999). Polyphenoloxidase activity and color of blanched and high hydrostatic pressure treated banana puree. J. Food Sci., 64: 42-45.

Pellegrini, M., R. Lucas-Gonzales, A. Ricci, J. Fontecha, J. Fernández-López, J. A. PérezÁlvarez and M. Viuda-Martos (2018). Chemical, fatty acid, polyphenolic profile, techno-functional and antioxidant properties of flours obtained from quinoa (Chenopodium quinoa Willd) seeds. Industrial Crops and Products, 111: 38-46.

Persson, M. (2009). Nutritionally optimized ice cream fats. Lipid Technol., 21(3), 62-64.

Pineli, L. D., R. B. Botelho, R. P. Zandonadi, J. L. Solorzano, G. T. de Oliveira, C. E. G. Reis and D. D. Teixeira (2015). Low glycemic index and increased protein content in a novel quinoa milk. LWT-Food Sci. and Technol., 63(2): 1261-1267.

Pizarro, P. L., E. L. Almeida, A. S. Coelho, N. C. Sammán, M. D. Hubinger and Y. K. Chang (2015). Functional bread with n-3 alpha linolenic acid from whole chia (Salvia hispanica L.) flour. J. of Food Sci. and Technol., 52(7): 4475-4482.

Repo-Carrasco-Valencia, R. A. M. and L. A. Serna (2011). Quinoa (Chenopodium quinoa, Willd.) as a source of dietary fiber and other functional components. Food Sci. and Technol., 31(1): 225-230

Reyes-Caudillo, E., A. Tecante, and M. A. ValdiviaLópez (2008). Dietary fibre content and antioxidant activity of phenolic compounds present in Mexican chia (Salvia hispanica L.) seeds. Food Chemi., 107(2): 656-663.

Sandoval-Oliveros, M. R. and O. Paredes-López (2013). Isolation and characterization of proteins from chia seeds (Salvia hispanica L.). J. of Agricultural and Food Chemi., 61(1): 193-201. 
Shetty, K., O.F. Curtis, R.E. Levin, R. Witkowsky and W. Ang (1995). Prevention of Vitrification Associated with in vitro Shoot Culture of Oregano (Origanum vulgare) by Pseudomonas spp. J. Plant Physiol., 147(3-4): 447-451.

Stratton, R. J., C. J. Green, and M. Elia (2003). DiseaseRelated Malnutrition: an evidence-based approach to treatment. CABI, Oxford.

Tsiplakou, E. and G. Zervas (2008). Comparative study between sheep and goats on rumenic acid and vaccenic acid in milk fat under the same dietary treatments. Livestock Sci., 119(1-3): 87-94.

Turan, S., M. Kirkland, P. A. Trusty and I. Campbell (1999). Interaction of fat and air in ice cream. Dairy Ind. Inter., 64(1): 27-31.
Turgut, T. and S. Cakmakci (2009). Investigation of the possible use of probiotics in ice cream manufacture. Inter. J. Dairy Technol., 62(3): 444-451.

Ulbricht, T. L. V. and D. A. T. Southgate (1991). Coronary heart disease: seven dietary factors. The lancet, 338(8773): 985-992.

Ullah, R., M. Nadeem, A. Khalique, M. Imran, S. Mehmood, A. Javid and J. Hussain (2016). Nutritional and therapeutic perspectives of Chia (Salvia hispanica L.): a review. J. Food Sci. and Technol., 53(4):1750-1758.

Yang, J., N. Zheng, J. Wang and Y. Yang (2018). Comparative milk fatty acid analysis of different dairy species. Inter. J. Dairy Technol., 71(2): 544-550.

\section{استخدام الكينوا والثيا في تحسين الخصائص الوظيفية وتعزيز الفوائد الصحية للمثلجات اللبنية والقثدية الطرية \\ صلاح أحمد خليفة

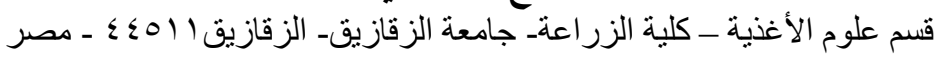

هدفت هذه الدراسة إلى تقييم استخدام الكينوا و الثيا لتحسين الخصائص الوظيفية وتعزيز الفوائد الصحية للمثلجات اللبنية والقتندية

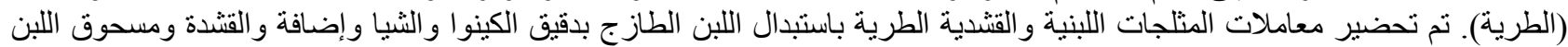

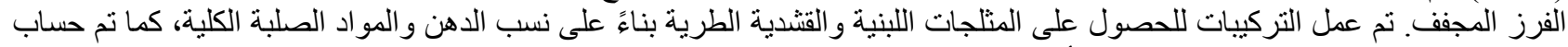

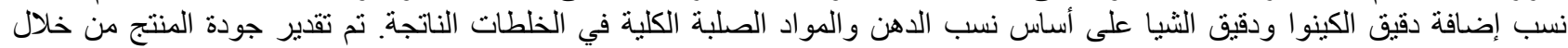

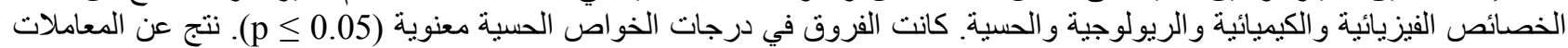

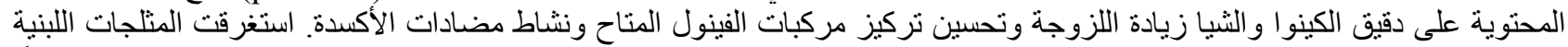

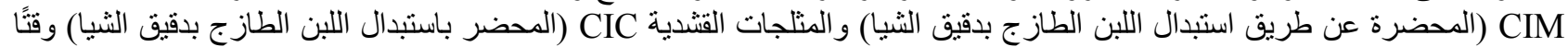

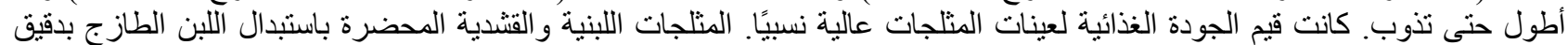

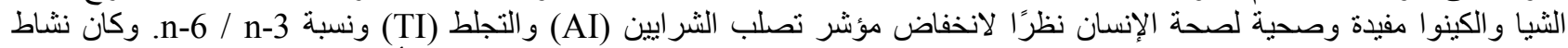

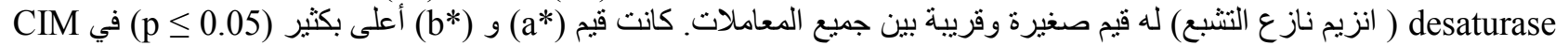

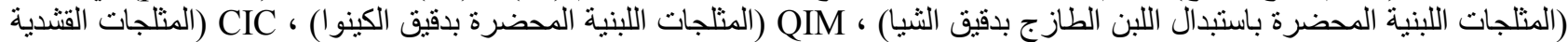
المحضر باستبدال اللبن الطازج بدقيق الثيا) ، QIC (المتلجات القشدية المحتوية على دقيق الكينو ال) و أقل (

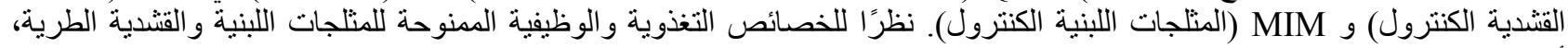

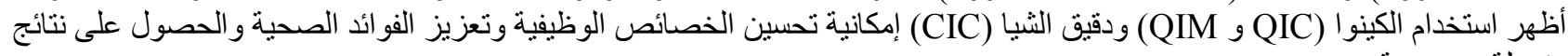
مفضلة ومر غوبة. 